\title{
REAL FORTE PRÍNCIPE DA BEIRA EM COSTA MARQUES - RO: UMA PERSPECTIVA ARQUEOLÓGICA PARA SUA PRESERVAÇÃO
}

\author{
Marcos Antonio Gomes de Mattos de Albuquerque ${ }^{i}$ \\ Veleda Christina Lucena de Albuquerque ${ }^{\mathrm{ii}}$
}

Resumo: O Real Forte Príncipe da Beira, em Rondônia, se constitui em um dos maiores fortes já construídos no Brasil. Abandonado, após a instauração da República, entrou em um processo de arruinamento, acelerado possivelmente por ações de pilhagem, como reza a tradição oral. Localizado na fronteira Oeste do País, em meio à Selva Amazônica, praticamente desapareceu da memória popular, até ser descoberto por uma missão militar que atravessava a área, já no século XX. Permaneceu abandonado até que, em 1930, com a criação dos Contingentes de Fronteiras, o Exército Brasileiro iniciou a construção de instalações militares nas proximidades do Forte. Tombado pelo Iphan em 1950, atualmente o se encontra sob a guarda do 10 Pelotão de Especial de Fronteira "Real Forte Príncipe da Beira" do Exército Brasileiro, que propicia sua conservação. Várias ações e estudos têm sido desenvolvidos visando a preservação daquele monumento. Este trabalho é resultante de uma visita de orientação técnica, a convite da Diretoria do Patrimônio Histórico e Cultural do Exército, que contou com a participação de especialistas de diferentes áreas. Nossas observações, aqui expressas, abordam a questão do ponto de vista arqueológico.

Palavras-Chave: Fortificação; Amazônia; Fronteira; Preservação de monumento.

Abstract: The Real Forte Príncipe da Beira, in Rondônia, is one of the largest forts ever built in Brazil. It was abandoned after the establishment of the Republic, it entered in process of destruction possibly accelerated by actions of looting as it says oral tradition. Located in the western border of the country, in the midst of Amazon jungle, it practically disappeared of popular memory, until a military mission that crossed the area, in the twentieth century, discovered it. It remained abandoned until, in 1930, with the creation of Contingentes de Fronteiras, the Brazilian Army started to build military installations near the fort. Listed by IPHAN in 1950, nowadays the fort is under the protection of 10 Pelotão Especial de Fronteira "Real Forte Príncipe da Beira" of Brazilian Army, which is responsible for its preservation. Several actions and studies have been carried out aiming the preservation of that monument. This work is a result of a technical visit, an invitation of Diretoria do Patrimônio Histórico e Cultural do Exército, which included several specialists of different areas. Our observations, expressed here, addressed the issue from an archaeological point of view.

Ltda.

veleda@brasilarqueologico.com.br

Key Words: Fortification; Amazon; Border; Preservation of monument. 


\section{Introdução}

O Real Forte Príncipe da Beira (RFPB) está localizado na margem direita do rio Guaporé, na fronteira natural do Brasil com a Bolívia, no município de Costa Marques, a sudoeste de Rondônia. O Forte se encontra atualmente sob a guarda do 10 Pelotão Especial de Fronteira "Real Forte Príncipe da Beira", do Exército Brasileiro, instituição que ocupa a área desde a década de 1930, tendo atuado desde então na salvaguarda daquele bem.

Construído na segunda metade do Século XVII, o Forte é um bem tombado federal, cuja coordenada geográfica no ponto central da Praça de Armas é $12^{\circ} 25^{\prime} 40.48^{\prime \prime S}$ e $064^{\circ} 25^{\prime} 22.50^{\prime \prime O}$. (Figura 1)

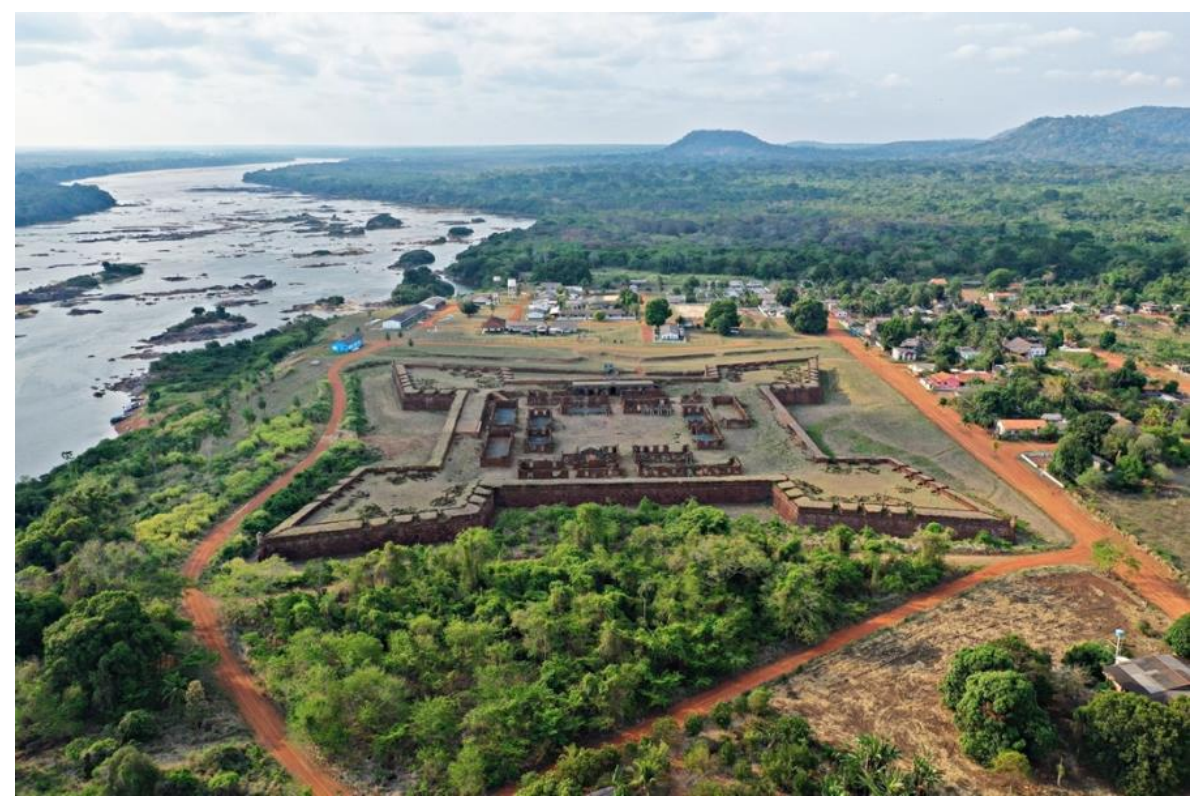

Figura 1: Vista de situação do Real Forte Príncipe da Beira às margens do Guaporé. Observe-se suas dimensões em relação às casas do entorno. Fonte: Arqueolog Pesquisas, 2020.

Por sua posição estratégica, o Real Forte Príncipe da Beira representa um dos demarcadores da fronteira Oeste do Brasil, tendo garantido a posse do território à colônia portuguesa, tanto legal quanto belicamente, quando se discutia os limites entre as terras de Portugal e Espanha. Permaneceu ativo até o final do século XIX, tendo sido abandonado após a instauração da República. Praticamente esquecido nos anos seguintes, foi quase que retomado pela floresta. 
"Descoberto" e "redescoberto" em 1911 e em 1913, permaneceu isolado, à mercê das intempéries e quiçá da pilhagem ${ }^{1}$.

A longo de sua história este forte não teria enfrentado combate armado, todavia sua presença certamente se impôs, provavelmente evitando eventuais tentativas de invasão daquela fronteira. Mas foi contra o tempo, contra as mudanças de armamentos, contra o abandono e as intempéries que suas estruturas lutaram todos estes anos, sobretudo a partir da instauração da República, quando foi abandonado. A perda das cobertas, certamente acelerou o processo de degradação; a queda do reboco foi outro fator que fomentou a desagregação das pedras que constituem as paredes. A livre implantação da vegetação seja destruindo os telhados, seja medrando entre as pedras, provavelmente impôs severas baixas à sua estrutura.

Sob a guarda do Exército a partir da década de 30, só em 07/08/1950, o Real Forte Príncipe da Beira foi tombado como Bem Patrimonial da União, inscrito no Arquivo Noronha Santos, sob o número 281, assentado no Livro Tombo Histórico²

Atualmente, o Real Forte Príncipe da Beira integra a lista dos 19 Fortes, candidatos a Patrimônio Mundial, como Bem Seriado, cujo conjunto "representa as inúmeras construções defensivas implantadas no território nacional, nos pontos que serviram para definir as fronteiras marítimas e fluviais do Brasil"3.

\section{Localização e Características Básicas do Real Forte Príncipe da Beira}

O Real Forte Príncipe da Beira representa uma das diversas estruturas fortificadas, construídas nas colônias americanas de Portugal, no século XVIII. De traçado italiano, com quatro baluartes, suas muralhas abrangem um perímetro de quase $1000 \mathrm{~m}$, ocupando com suas defesas externas uma área de mais de 5 hectares.

Trata-se de uma construção em pedra argamassada, com paredes internas rebocadas, cujos cunhais, ombreiras, vergas e soleiras, além da portada, são em cantaria. As muralhas são revestidas com pedras trabalhadas, bem como seus merlões. O fosso, circundando o forte foi,

\footnotetext{
${ }^{1}$ FERRAZ, A. L. Pereira. Real Forte Príncipe da Beira. Revista do Serviço do Patrimonio Historico e Artistico Nacional, N.2 Min isterio da Educação e Saude. 1938 -p 147

2 http://portal.iphan.gov.br/ans/ № Processo:0395-T-50

${ }^{3}$ http://portal.iphan.gov.br/pagina/detalhes/1611/
} 
pelo menos em parte, escavado na rocha, fornecendo parte do material utilizado na construção.

Iniciado em 1776, em dois anos "o circuito externo das muralhas estava concluído" 4 . Em 1778, estavam concluídos os reparos de três de seus baluartes e de duas de suas cortinas, entretanto o baluarte a Sudeste e as cortinas contíguas não haviam recebido ainda o reparo. A planta deste mesmo ano mostra que, das obras internas, só a capela havia sido concluída.

Sabe-se ainda que, em 1789, grande parte da contra escarpa do fosso restava por escavar. ${ }^{5} \mathrm{~A}$ planta de obras daquele mesmo ano mostra que apenas um baluarte - o do lado Noroeste - e a metade da cortina para o rio estavam prontos, o resto dos parapeitos estava incompleto.

O acesso ao forte, cruzando o fosso, se fazia sobre uma ponte, parte fixa, parte levadiça. Além das plantas, seu frontão testemunha na arquitetura parte do mecanismo usado para mobilizar o trecho da ponte.

Este artigo tomou por base o relatório apresentado à Diretoria do Patrimônio Histórico e Cultural do Exército - DPHCEx, que nos convidou a participar da Visita de Orientação Técnica (VOT), no Comando Militar da Amazônia, visando o prosseguimento do Projeto de Revitalização e Restauro do Real Forte Príncipe da Beira, em Costa Marques, RO.

Neste sentido nos coube avaliar as atuais condições do Bem, do ponto de vista arqueológico, sugerindo ações que possam contribuir nas obras de preservação e/ou restauração, e mesmo no entendimento de suas estruturas, função e uso.

Paralelamente, considerando que o Real Forte Príncipe da Beira integra a lista das 19 fortificações brasileiras que pleiteiam, como Bem Seriado, o título de Patrimônio Mundial, incluímos ainda a realização de tomadas aéreas que permitissem a elaboração de uma ortofotocarta do forte e seu entorno imediato, além de um modelo digital de elevação, e de um modelo 3D da fortificação. Com este último modelo se busca padronizar para as 19 fortificações integrantes do Bem Seriado esta forma de apresentação.

Em se considerando que o Real Forte Príncipe da Beira foi alvo de pesquisa arqueológica, nossa abordagem buscou se ater às áreas não referidas no relatório daquela pesquisa, que visou

${ }^{4}$ Castro, 2009, p 464

${ }^{5}$ Ver planta p 465, em Castro 2009. 
"identificar e levantar aspectos das fundações dos seguintes locais: Trânsito Superior, Poterna, Cortinas e uma das Edificações internas (item 1.10.00)", o que implicou em intervenções no sítio histórico, através de escavações.

Por outro lado, a avaliação aqui relatada foi realizada não com base em escavação arqueológica, mas em bases cartográficas e de avaliação de superfície do terreno, bem como das condições das estruturas.

Dentro do espírito de colaboração acadêmica, é lícito admitir-se que diferentes disciplinas interagem com a Arqueologia Histórica para acessar dados necessários. Do ponto de vista da Arqueologia Histórica, tais objetivos são legítimos e não podem ser rejeitados ou ignorados. $\mathrm{Na}$ realidade, uma interdependência, pois, estas mesmas bases podem servir de suporte às hipóteses e assertivas arqueológicas.

Experiências anteriores em escavações arqueológicas de áreas fortificadas como o Forte Real (velho) do Bom Jesus, Forte do Brum, Fortim de Tejucupapo (todos em PE) e Fortim Bass (em $\mathrm{AL})$, tem demonstrado o quanto a pesquisa arqueológica tem contribuído para evitar ou reduzir a perda de informações e, gradativamente, reconstituírem-se aspectos da vida dos cidadãos nos primeiros tempos do Brasil. A história de suas edificações, do modo de vida e dos hábitos de seus moradores, de suas preocupações cotidianas, através do modo como se aplicavam, ou não, na execução das obras, têm sido observados por meio da documentação material de seus sítios históricos. É o caso da muralha que defendia a cidade do Recife, em sua face voltada para o continente, localizada tanto no trecho depois ocupado pela Sinagoga Kahal Zur Israel. Uma muralha que se acreditava ter sido apenas projetada, mas não executada. Sabe-se hoje o quanto representava de preocupação para a população holandesa, nos primeiros anos da ocupação do Brasil, os ataques das Companhias de Emboscada que os privavam de obter os alimentos naquela terra ${ }^{6}$.

Dentre a documentação histórica que tem servido de base, merece particular destaque a cartografia coeva. Em trabalhos anteriores, se mostraram particularmente úteis os mapas elaborados por cartógrafos holandeses, bem como as ilustrações, sejam as iluminuras sejam os desenhos ou quadros holandeses que retratam aquela área específica. Este tipo de abordagem foi anteriormente utilizado pela equipe, em trabalho realizado em Penedo (Alagoas), quando

${ }^{6}$ Ver http://www.brasilarqueologico.com.br/ 
os trabalhos de Marcgraf e de Frans Post, por exemplo, foram particularmente úteis. Muito importantes também foram os apontamentos e desenhos do comandante das tropas holandesas coronel Crestofle d'Artischau Arciszewsky ${ }^{7}$

Para o estudo do Real Forte Príncipe da Beira se dispõe hoje de diferentes plantas, documentos que foram sucessivamente levantados por diferentes autores que se dedicaram a pesquisá-lo. São plantas desde o seu projeto, a plantas voltadas ao acompanhamento das obras, que permitem avaliar-se as prioridades de defesa, a urgência para com as frentes a serem defendidas. Todavia, parece faltar maiores informações cartográficas, a partir de quando foram definidos os limites entre as Coroas Portuguesa e Espanhola até o abandono do Forte, no final do século XIX. Assim, pelo que podemos observar, não se dispõe de documento que apontasse as condições de 'as built' no século XIX. De modo análogo, também não tivemos acesso (caso exista), a um mapa de danos das edificações, quando de sua redescoberta. Todavia, naquela ocasião, já se dispunha da fotografia. E naquele momento, as fotografias tomadas para comprovação do achado, bem servem hoje para se vislumbrar muitos detalhes do que fora construído. Os danos, então presentes, acumulados nos 25 anos de abandono, não impediram de conhecer-se seu tipo de coberta, a presença de portas e janelas, o revestimento das paredes. Uma documentação preciosa. Apesar de ter sido redescoberto, o Forte continuou em seu abandono, até que em 1934, em decorrência da visita da Comissão de Inspeção de Fronteiras, em 1930, e da criação dos Contingentes de Fronteiras, o Exército Brasileiro começa a construção de instalações militares nas proximidades do Forte.

Tem-se assim que o Forte permaneceu abandonado por cerca de 45 anos, e em quase meio século, a natureza se encarregou de retomar seu espaço. $O$ avanço da vegetação durante os primeiros 24 anos (1889-1913) parece ter causado menos danos (como se pode observar nas fotos), mas certamente abriram o caminho para o que teria acontecido nos últimos 20 anos. Segundo relatos, a vegetação que permeava o Forte fora removida em 1913, mas o Forte permaneceu abandonado até cerca de 1934.

Atualmente se dispõe de farto material fotográfico do Forte, inclusive disponibilizado na Internet, mas os recursos de interpretação a partir de imagens vão além do registro iconográfico. Uma base fotogramétrica permite explorar-se com maior facilidade e boa

\footnotetext{
7 Dois panfletos de Cristóvão Artischevski noticiando o Cerco e a Conquista de Porto Calvo pelo Conde de Nassau em 1637.Traduzidos por N.B Teensama.
} 
precisão a distribuição espacial, volumetria, perfis etc., aspectos estes de grande interesse em uma análise técnica.

Ademais, os Modelos de Elevação permitem analisar-se em detalhes as resultantes da erosão/sedimentação, propiciando a busca por eventuais agentes de deterioração. Neste sentido, são particularmente úteis os perfis topográficos que podem ser obtidos com base nos Modelos de Elevação.

Para a geração da base cartográfica, foram realizadas as seguintes etapas ${ }^{8}$ :

Voo aerofotogramétrico, com o emprego de veículo aéreo não tripulado - VANT (drone multirotor), além da utilização de programa específico para mapeamento;

- Restituição; ou seja, o processo de elaboração de mapas, a partir de fotografias aéreas métricas e de dados de controle geodésico, por meio de instrumentos ou sistemas fotogramétricos, consistindo na transferência dos elementos da imagem fotográfica sob a forma de vetores, com o uso de programas específicos.

- Por fim, foi possível obter-se o ortofotomosaico ${ }^{9}$ passível de ser utilizado nos programas de base SIG, em formato shapefile.

- A partir do Modelo Digital de Elevação (MDE) ${ }^{10}$ foram ainda processadas as cotas obtidas de modo a constituir-se as curvas de nível com equidistância de 01 e de 0,5m.

Os produtos gerados no processamento das imagens coletadas através da aerofotogrametria [Modelo Digital de Superfície (MDS), Modelo Digital de Elevação (MDE), ortofotomosaico e curvas de nível - foram convertidos em formato shapefile, conforme é recomendado pelo Iphan para o mapeamento de sítios arqueológicos.

Buscou-se, deste modo, apresentar como resultado o registro das dimensões dos espaços edificados e do pátio interno da fortificação histórica, da sua altimetria externa e das curvas de nível do terreno situado no seu entorno imediato.

As fotografias aéreas constituíram ainda as bases para o estudo progressivo do arruinamento das formas da fortificação, através de modelos de elevação e de perfis no interior da fortificação, gerados a partir de estudos topográficos com base em curvas de nível.

\footnotetext{
${ }^{8}$ As definições foram extraídas do “Dicionário Cartográfico", 4aㅡ Ed., Cêurio de Oliveira, Rio de Janeiro, 1993.

${ }^{9}$ Ortoimagem - fotografia ou imagem com uma projeção ortográfica. (perpendicular ao terreno).

10 Modelo Digital de Elevação (MDE) é uma representação matemática/computacional contínua da topografia do terreno distribuída espacialmente às variações de altitude numa área baseada e definida sobre um plano cartográfico num conjunto de coordenadas $\mathrm{X}, \mathrm{Y}$ e Z. As coordenadas $\mathrm{Z}$ representam valores da altitude e profundidade num modelo tridimensional que contenha o atributo elevação A partir dos modelos se pode gerar fatiamentos nos intervalos desejados e perspectivas tridimensionais. http://sigmats.com.br/index.php?option=com_content\&view=article\&id=131\&/temid=241
} 
- Elaboração de fonte cartográfica digital para o estabelecimento de modelos possíveis ${ }^{11}$

- Levantamento topográfico preliminar e geração de modelos digitais.

Visa realizar o levantamento topográfico, georreferenciado da área estimada da fortificação histórica e seu entorno imediato. Esta etapa de execução foi dimensionada para atender toda a área limítrofe e o próprio forte.

O levantamento topográfico do terreno foi realizado a partir de imagens aéreas tomadas a distintas alturas, com sobreposição de, no mínimo, $85 / 75 \%$. Os voos foram devidamente solicitados ao Departamento de Controle do Espaço Aéreo - DECEA e com a devida concordância do serviço de controle do aeródromo local. As imagens foram processadas de modo a se obter arquivos em shape e tratadas com softwares capazes de gerar um ortofotomosaico da área de abrangência, além de modelos de elevação e 3D. A partir dos modelos assim obtidos foram geradas as curvas de nível com equidistância de 0,25m. O nível de acurácia do conjunto foi da ordem de 0,8 no x, de 0,8 no y e 1,8 em z, com o Ground Sample Distance - GSD de 1,2 cm por pixel, suficientes para as análises a serem efetuadas.

- Reconstituição topográfica das formas do terreno

Com base nas grades de elevação foram gerados perfis de terreno que privilegiaram cada um dos componentes da estrutura de defesa. Tais perfis permitiram estabelecer-se uma aproximação das áreas de erosões e as de sedimentação de modo a avaliar-se as deformações sofridas pela estrutura. A confrontação de tais dados com os modelos preconizados para estruturas de defesa coevas, propiciaram uma aproximação confiável do modelo construído.

O modelo teórico assim gerado poderá vir a ser confrontado com os dados de campo obtidos a partir de escavações arqueológicas que venham a ser realizadas, quando a estratigrafia revelada, sobretudo nas áreas de deposição trará detalhes precisos das estruturas preexistentes.

Na realidade, o trabalho por nós realizado representa uma visão de aspectos de interesse arqueológico, que podem já ter sido tratados por outros autores que não tenhamos tido acesso face à exiguidade de tempo para atender a visita de orientação técnica - VOT.

\footnotetext{
${ }^{11} \mathrm{Na}$ execução do aerolevantamento contamos com a coparticipação da AeroRegistro, através do arqueólogo Yuri Menezes.
} 
Aspectos que, do ponto de vista arqueológico, poderiam vir a contribuir com o Projeto de Revitalização e Restauro do Real Forte Príncipe da Beira

Inicialmente gostaríamos de enfocar a questão da amplitude da área de tombamento atribuída ao Real Forte Príncipe da Beira.

A Inscrição $n^{\circ} 281$ do Livro de Tombo Histórico descreve de um modo pouco preciso a amplitude do Bem. Inicialmente descreve outras obras de defesa que o precederam na fronteira com a Bolívia, à margem do Guaporé, mas parece restringir o tombamento ao Real Forte Príncipe da Beira. A descrição apresentada sugere que o tombamento se restringe ao polígono amuralhado, incluindo um possível revelim à frente da porta principal:

\begin{abstract}
Apresenta plano quadrangular, amuralhado em cantaria e com baluartes nos ângulos - consagrados à Nossa Senhora da Conceição, Santa Bárbara, Santo Antônio de Pádua e São José Avelino -, seguindo os preceitos da arquitetura militar da época, inspirado no sistema elaborado por Vauban. Sobre o terrapleno, há 14 grandes edifícios de pedra lavrada, denominada "pedra canga", e argamassa, que abrigavam os quartéis da guarnição e a capela. A porta principal contava com ponte levadiça sobre fosso seco e era protegida por revelim (Barão de Melgaço, apud Ferreira, M.R. 1961) ${ }^{12}$.
\end{abstract}

Certamente, à época de seu tombamento (1950), não havia estudos mais aprofundados acerca daquela fortificação, ainda pouco conhecida. Tanto que atualmente o Iphan tem se debruçado no sentido de reestudar o polígono de tombamento. Neste sentido gostaríamos de reforçar alguns pontos que consideramos importantes. Inicialmente um ajuste na nomenclatura utilizada: onde se lê:

Sobre o terrapleno, há 14 grandes edifícios de pedra lavrada,...", melhor se diria "No interior da praça de armas há ..." Do mesmo modo quando se refere "... com ponte levadiça sobre fosso seco e era protegida por revelim ...", melhor seria "... protegida por um glacis." ${ }^{13}$

Possivelmente a referência à presença de um revelim estaria baseada na descrição de uma planta, um dos projetos elaborados para aquele forte, substituído por outros. Trata-se de um Projeto dos idos de 1775 (Figura 2).

\footnotetext{
${ }^{12}$ A referência a um 'revelim' é encontrada em documento do Barão de Melgaço, apud Ferreira, M. R, 1961, citado por Hiram Reis e Silva.

${ }^{13}$ Observa-se que diferentes relatos fazem referência a quantidades distintas de edificações na praça de armas. Tais discrepâncias, muitas vezes parece refletir o número de edificações apontadas nas diferentes plantas.
} 


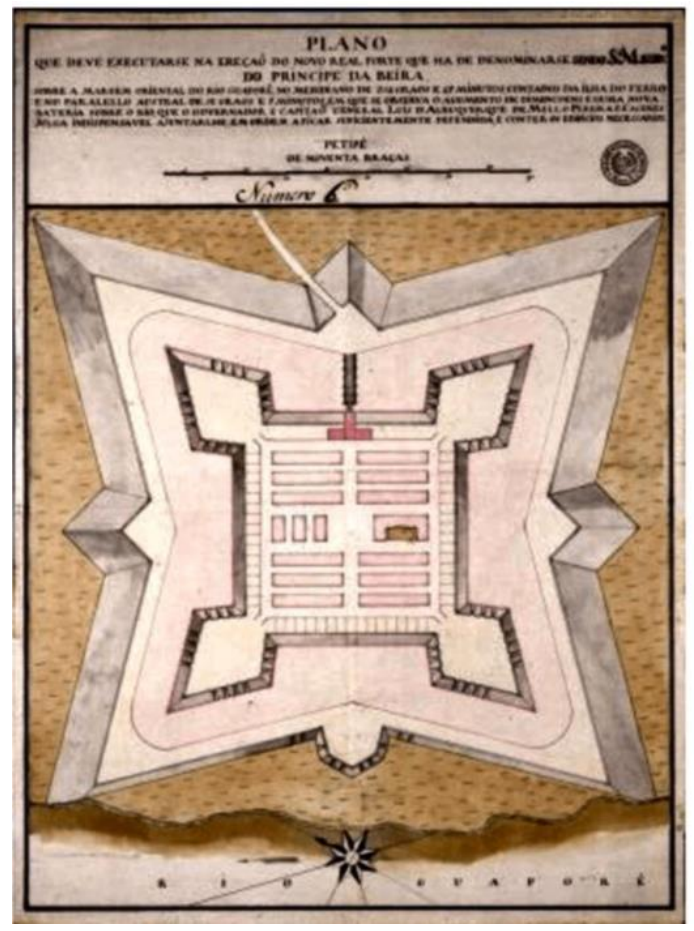

Figura 2: Plano do Forte Principe da Beira, Mato Grosso, ca. 1775. Cartografia do Arquivo Ultramarino, Lisboa.

Outro ponto que gostaríamos de ressaltar é o fato de que as obras de defesa do RFPB se estendem além do corpo da muralha e do fosso. Sua esplanada em parte ainda continua intacta, ou pelo menos, em parte conservada. Cumpre ressaltar que, embora conste nas plantas de diversos fortes brasileiros, praticamente não foram preservados os glacis. É particularmente digno de nota, a disposição defasada do glacis no RFPB, que permite o acesso ao fosso, sem deixar a descoberto a porta principal. Aquela estrutura de defesa é hoje muito rara no Brasil, se não for uma das únicas ainda preservadas (Figuras 3 e 4).

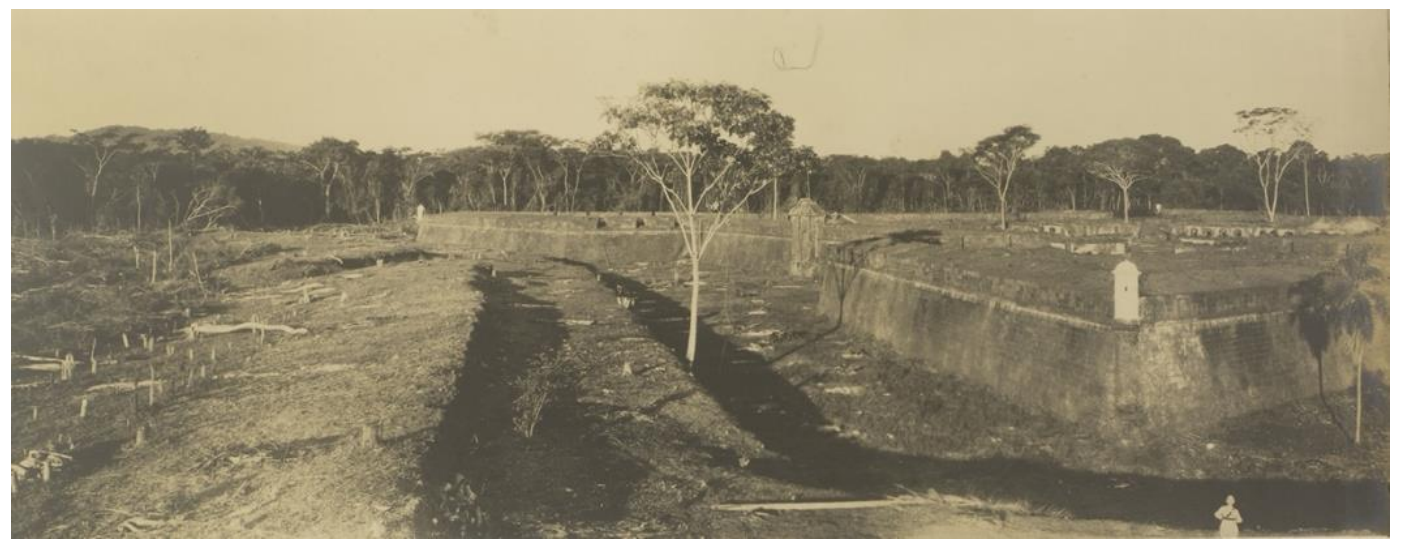

Figura 3: Defesas externas do Forte; além da muralha o fosso, o caminho coberto e a explanada que protegia as muralhas. Foto do Major Thomaz Reis, 1917. 


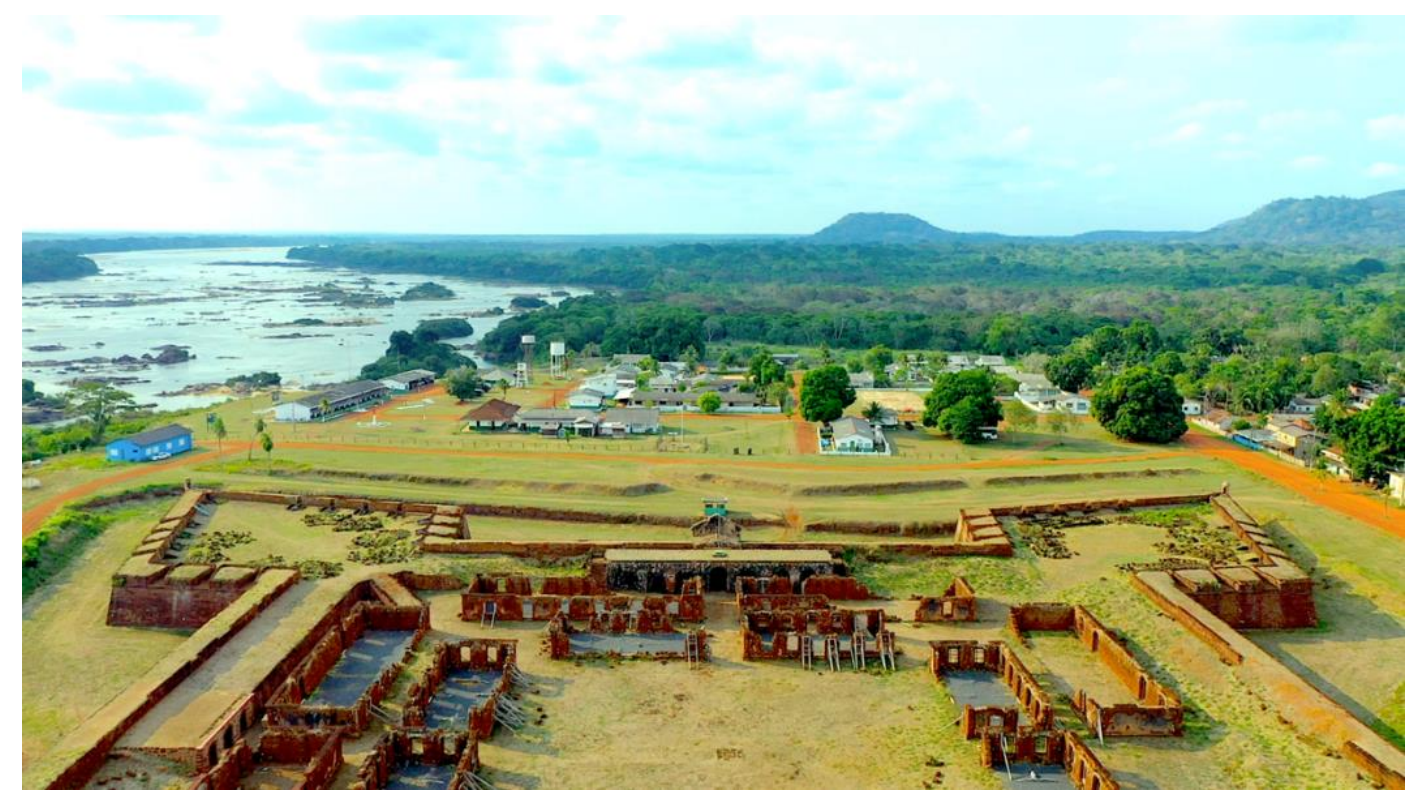

Figura 4: Entre o fosso e a estrada atual, observa-se perfeitamente o glacis, cuja abertura de acesso não deixa desprotegida a porta principal. Acervo Arqueolog Pesquisas, 2020.

Como bem observou o mestre Giovani Barcelos "...o monumento é muito mais do que as muralhas, e em especial naquela região do Vale do Guaporé, não se restringe à apenas uma construção" (Barcelos, 2018, p. 110).

Ademais, levando em conta a inscrição do Bem no Livro Histórico, devemos considerar que o entorno próximo ao Forte ainda guarda muitos aspectos da história da integração daquele território às fronteiras brasileiras. São testemunhos dos modos de fazer, das soluções encontradas para fazer face às condições naturais, como é o caso do regime fluvial de seus rios, com seus períodos de cheias, regulares e irregulares, dificuldades logísticas, de acesso às fontes de matéria prima, às dificuldades no transporte. Desde a escolha do terreno, quando cheias irregulares promoveram a perda das fortificações que antecederam o RFPB, às soluções encontradas para obtenção dos materiais necessários à construção, os caminhos utilizados, os meios de transporte disponíveis.

Alguns destes testemunhos são hoje conhecidos, ainda que escondidos em meio à mata. Outros poderão vir a ser descobertos, à medida que se invista em trabalhos de reconhecimento naquele entorno.

Além das ruínas das antigas fortificações com que se deu início a sistematização da ocupação da margem do Guaporé, pouco mais de $2 \mathrm{~km}$ à jusante do RFPB, o fortim da Conceição e posteriormente o Forte Bragança, são também conhecidas as ruínas de um forno e de uma casa de pólvora, mais próximas ao Forte. Uma terceira estrutura, esta ainda pouco conhecida, 
e sobretudo não efetivamente identificada, é referida como o 'labirinto', de que se tratará adiante.

Quando da visita de orientação técnica no Comando Militar da Amazônia, por solicitação da Diretoria do Patrimônio Histórico e Cultural do Exército - DPHCEx, com vista ao prosseguimento do Projeto de Revitalização e Restauro do Real Forte Príncipe da Beira, em Costa Marques, RO, o aspecto que a todos tem preocupado é o gradativo tombamento das estruturas internas do Forte.

Neste sentido duas questões se põem de forma associada: o que teria dado início ao processo (nestes termos a continuidade do processo e possíveis fatores de aceleração) e propostas para conter ou reverter o processo. $\mathrm{O}$ primeiro passo foi dado desde o início do século $\mathrm{XX}$, quando a

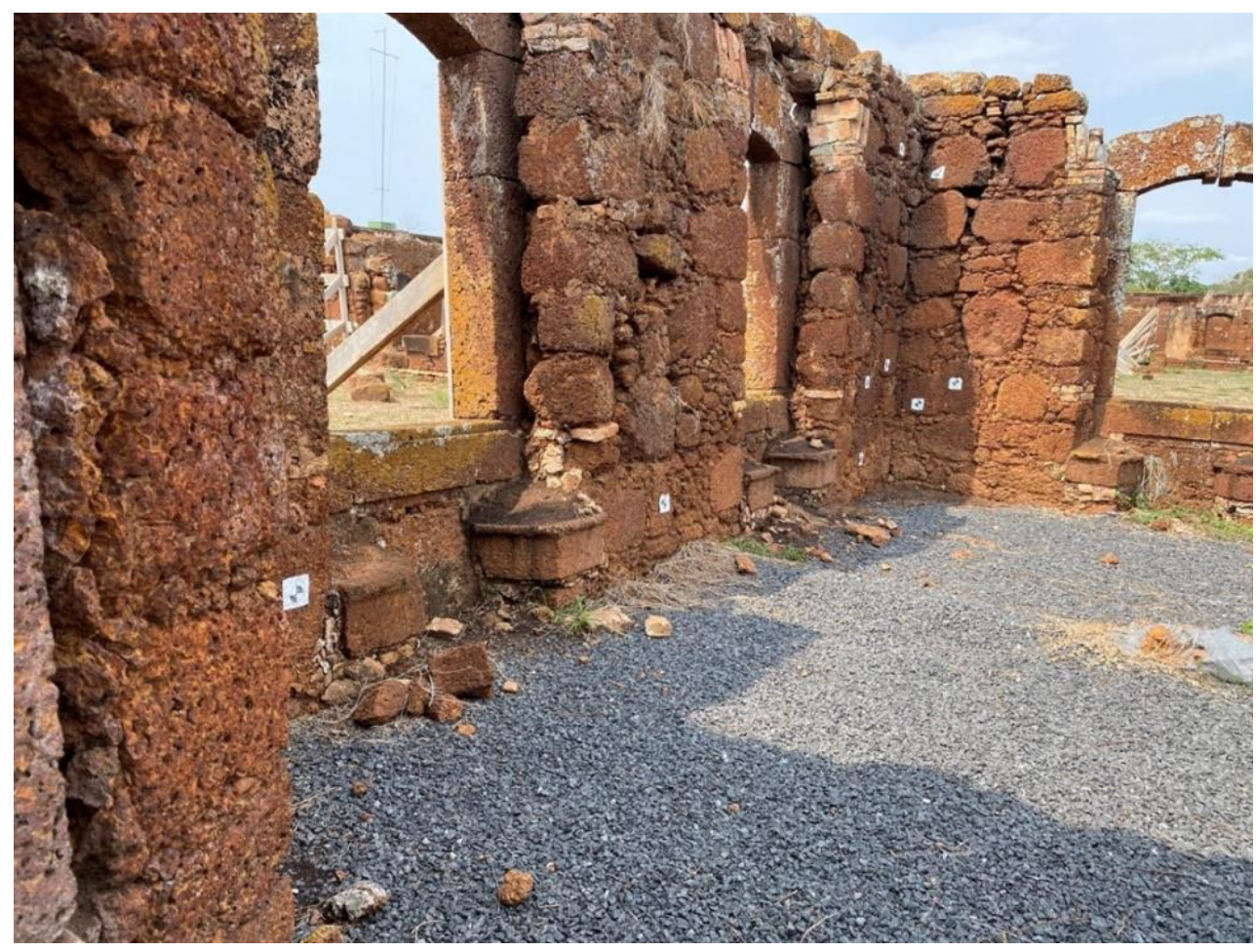

Figura 5: Detalhe do interior de um dos quartéis, onde se pode observar o avanço do arruinamento, com o deslocamento de paredes e das vergas. (Fonte: Arqueolog Pesquisas 2020).

expedição Rondon tomou a iniciativa de remover a vegetação invasora que se instalara no entorno, no interior e mesmo sobre as estruturas do forte. Anos mais tarde, com a implantação do Pelotão de Fronteira, quando o Exército tomou a si o encargo de manter o Forte, livre da vegetação que medrava entre suas pedras, o ritmo da degradação das estruturas foi mais uma vez desacelerado (Figura 5). 
Mas outros elementos além da força das raízes atuaram promovendo a ruptura do equilíbrio. Provavelmente a remoção da coberta, condição já encontrada nos idos de 1911/13, tenha sido um vetor mais contundente. Tanto no sentido da exposição mais direta às águas da chuva, quanto na falta das amarras representadas pelo madeirame e o próprio peso das telhas. Outro fator certamente decisivo teria sido a remoção dos 'gatos' que uniam as paredes:

Os artigos de metal, carcomidos de ferrugem, tendo sido grande porção de ferragem dos reparos das portas, da palamenta [necessários ao serviço de uma boca-de-fogo], etc., arrancada e vendida aos Bolivianos, a troco de víveres, sem excetuar os gatos de ferro que prendiam a obra de cantaria (https:Ilwww.ecoamazonia.org.br/2020111/terceira·margem·parte-Ilo p. 4).

Como bem se pode observar nas fotografias tomadas pela Expedição Rondon, após a remoção da vegetação, quase a totalidade das estruturas internas já não apresentava coberta, mas as paredes aparentemente ainda se mostravam a prumo (Figuras 6, 7 e 8).

E mais, a maioria das paredes ainda conservava o reboco; as vergas e ombreiras permaneciam garantindo os vãos. Um aspecto que chama a atenção no conjunto é o fato de que os vestígios das cobertas não podem ser percebidos nas fotos. Não se vê vestígios quer das telhas quer das linhas apodrecidas. Teriam sido removidas na limpeza? Uma análise mais acurada da fotografia mostra, entretanto, várias pedras no chão; possivelmente partes da cornija. O desabamento do telhado poderia ter arrastado as pedras que coroavam as paredes; pode-se observar, em vários pontos, que as cornijas já não restavam sobre o topo das paredes. No caso de ter havido um desabamento do telhado, grande quantidade de fragmentos de telhas deveria cobrir o chão, constituindo um registro arqueológico. Por outro lado, caso não houvesse este registro, possivelmente as telhas teriam sido removidas, antes do desabamento, para reutilização alhures, deixando as estruturas a descoberto.

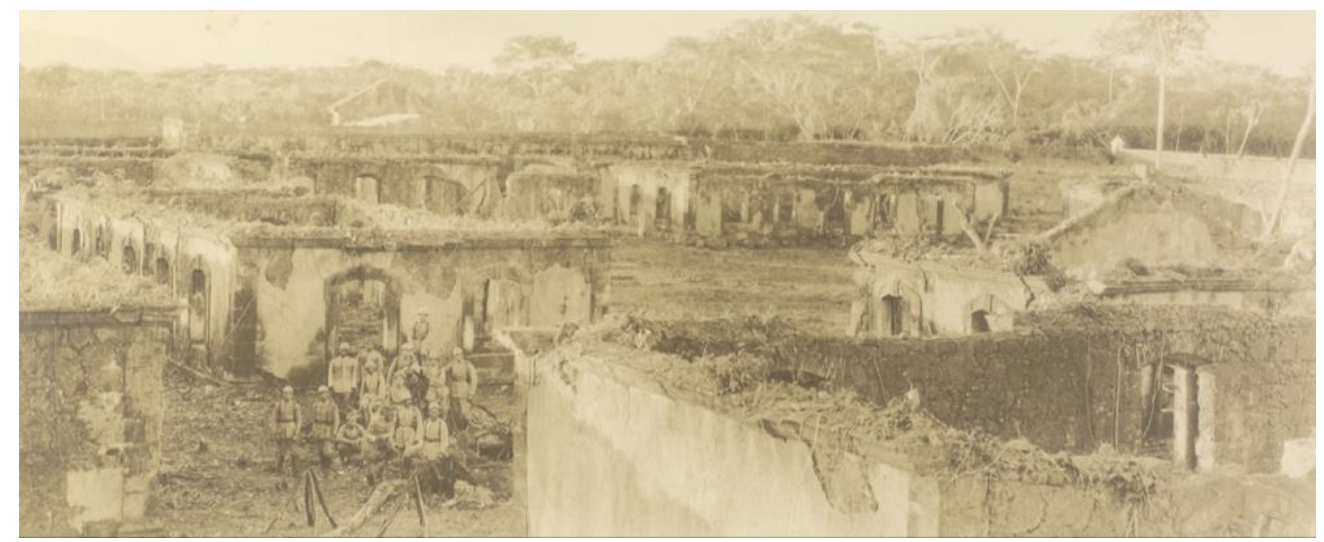

Figura 6: Interior do Forte Por B. Rondon - Arquivo Nacional, Domínio público. Fonte: https://commons.wikimedia.org/w/index.php?curid=84829404. 


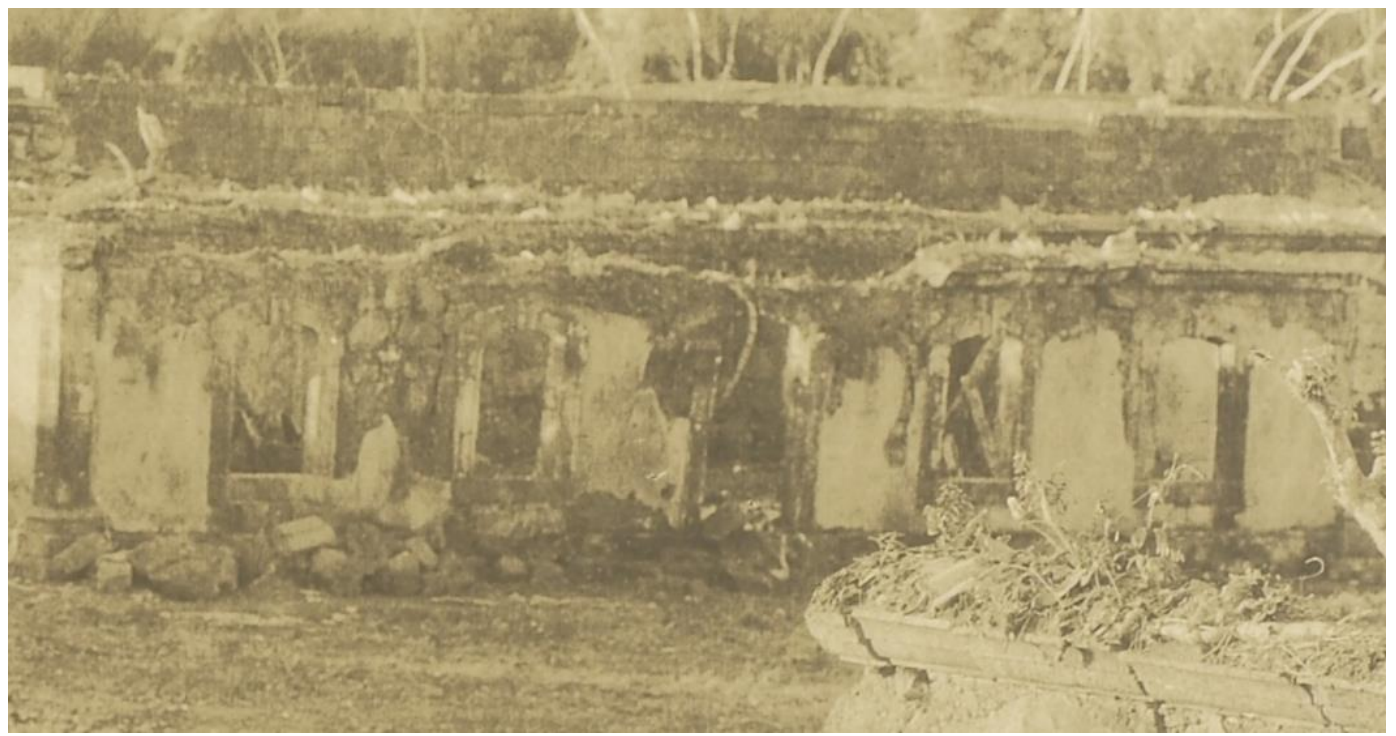

Figura 7: Detalhe da imagem anterior. Por B. Rondon - Arquivo Nacional, Domínio público. Fonte: https://commons.wikimedia.org/w/index.php?curid=84829404.

Mas, nesta mesma fotografia, algumas rachaduras já se mostram bem visíveis, todavia, no conjunto, as paredes ainda se mostravam aparentemente a prumo (Figura 8).

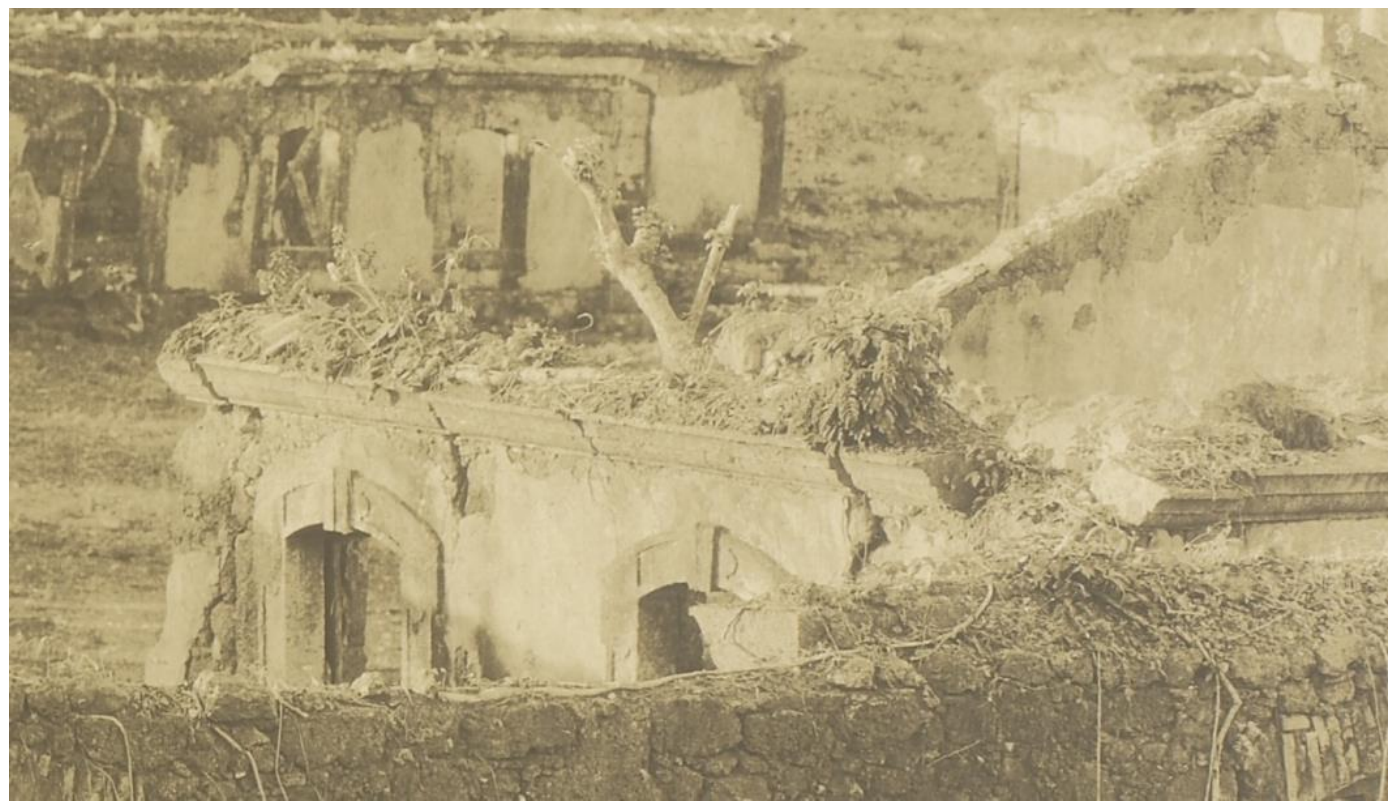

Figura 8: Outro detalhe da mesma imagem, onde já se observam rachaduras. Por B. Rondon - Arquivo Nacional, Domínio público. Fonte: https://commons.wikimedia.org/w/index.php?curid=84829404.

Atualmente, passados pouco mais de um século, praticamente todas as estruturas internas se mostram em risco, apresentando diferentes gradientes de inclinação; algumas delas já tombadas (Figura 9). 


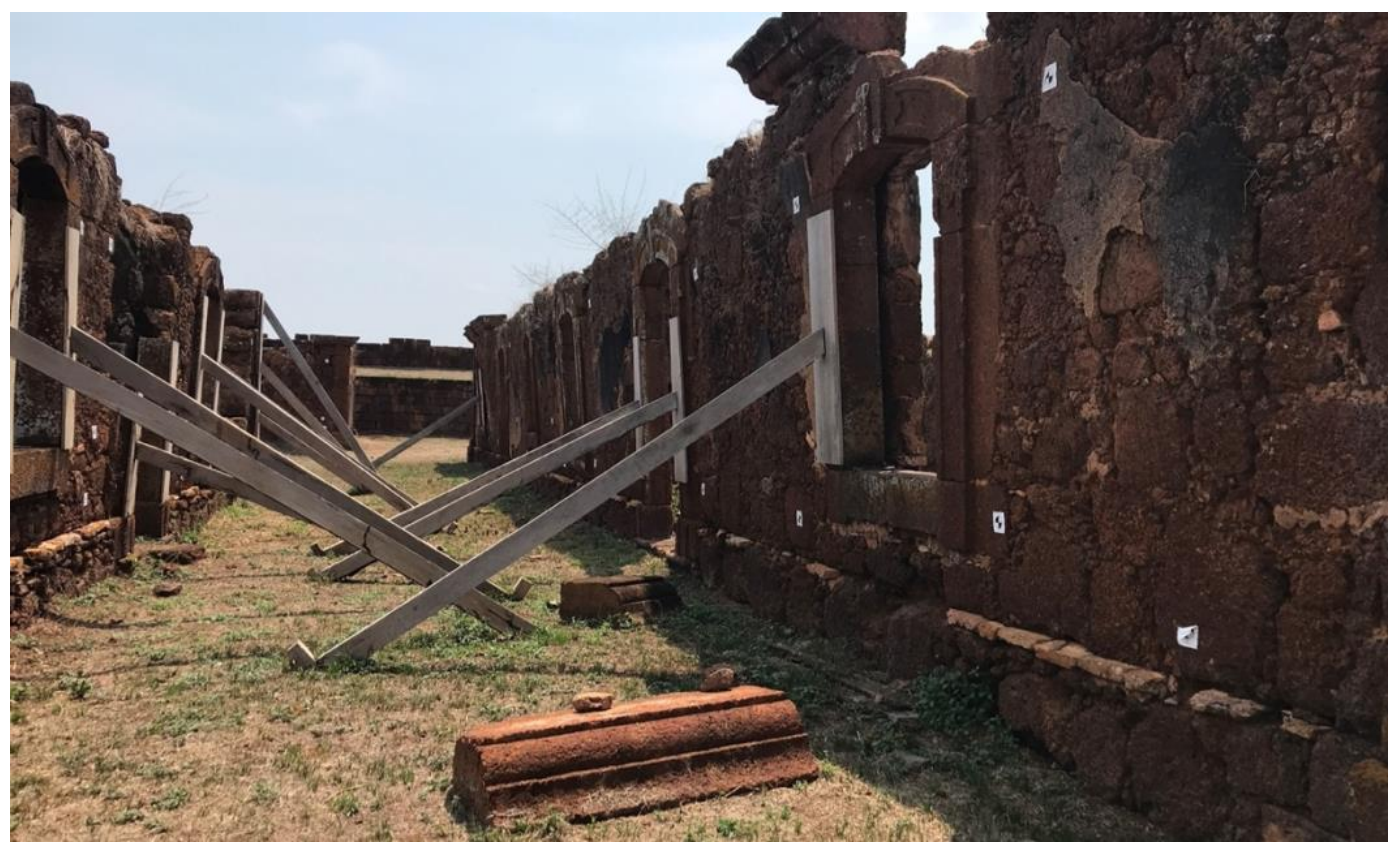

Figura 9: Vista de um conjunto de edificações na praça de armas, onde, com base nos escoramentos aplicados, se pode perceber a tendência geral de inclinação das paredes para o exterior de cada edificação. Fonte: Arqueolog Pesquisas 2020.

Outra vez analisando-se o conjunto a partir de imagens, pode-se observar que como tendência geral, as paredes se inclinam no sentido do lado externo de cada edificação, como se lhes faltasse a amarração do conjunto. Amarração que possivelmente seria suprida pelos cunhais (muitos ainda presentes) pelos 'gatos' e quiçá pelo madeiramento e (peso das) telhas.

A hipótese de associação da inclinação das paredes, com eventos sísmicos, como aquele relatado em 1882, nos parece improvável, salvo se tivesse havido um fraturamento diferenciado na camada de canga, que the serve de base.

Um outro ponto que gostaríamos de destacar é o risco real promovido pelo arruinamento de algumas estruturas, como é o caso de partes da contramuralha, que vem permitindo o desmoronamento do reparo e o consequente assoreamento da praça de armas. Como se pode observar no perfil construída a partir do Modelo Digital de Elevação (MDE), parte do terraplano se mostra arruinado, escoando em direção à praça de armas.

Na figura 10 se pode ver à esquerda, o terrapleno em sua condição normal, contido pela estrutura, enquanto, à direita o perfil mostra o terrapleno desmoronado, com fuga de material face a ausência da contramuralha, enquanto que a Figura 11 mostra o processo de fuga de material em ambas as cortinas, assinaladas nas extremidades da linha amarela. 


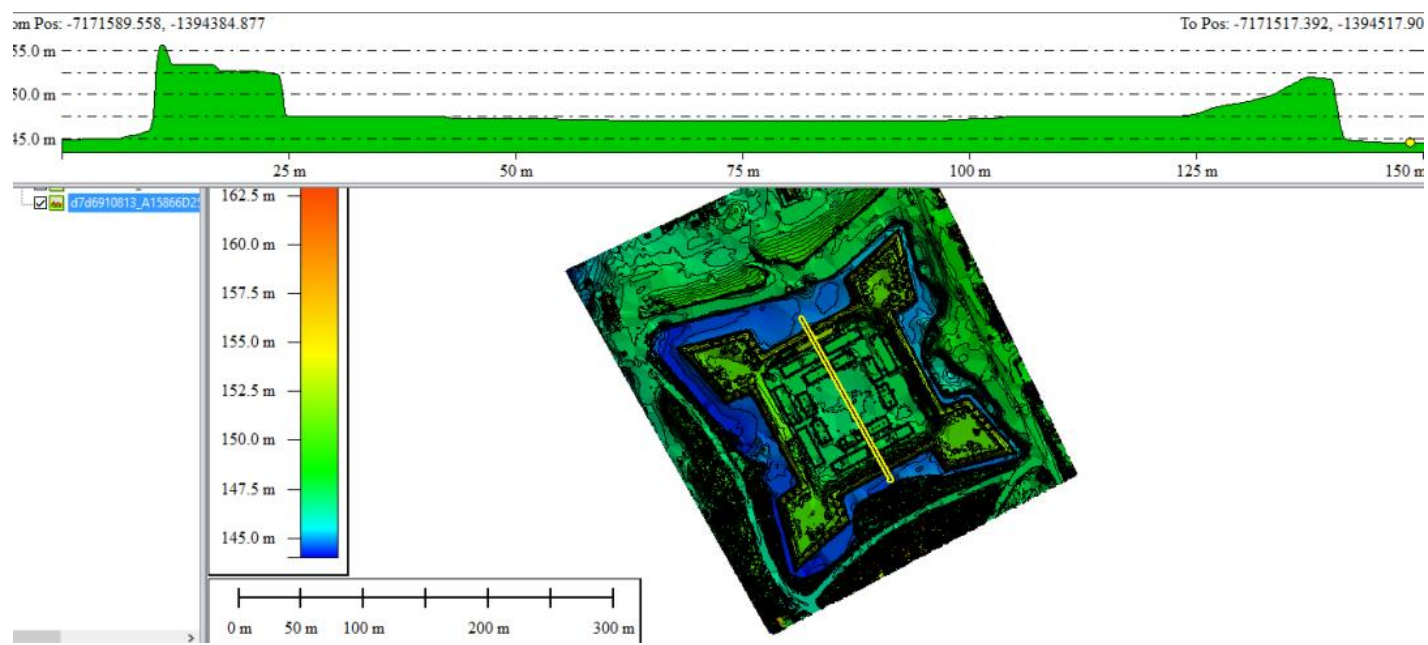

Figura 10: O perfil estabelecido na linha amarela que corta o MDE. Observe-se à esquerda o terrapleno contido pela contramuralha, que já não existe à direita, permitindo o desmoronamento do reparo. Fonte: Arqueolog Pesquisas 2020.

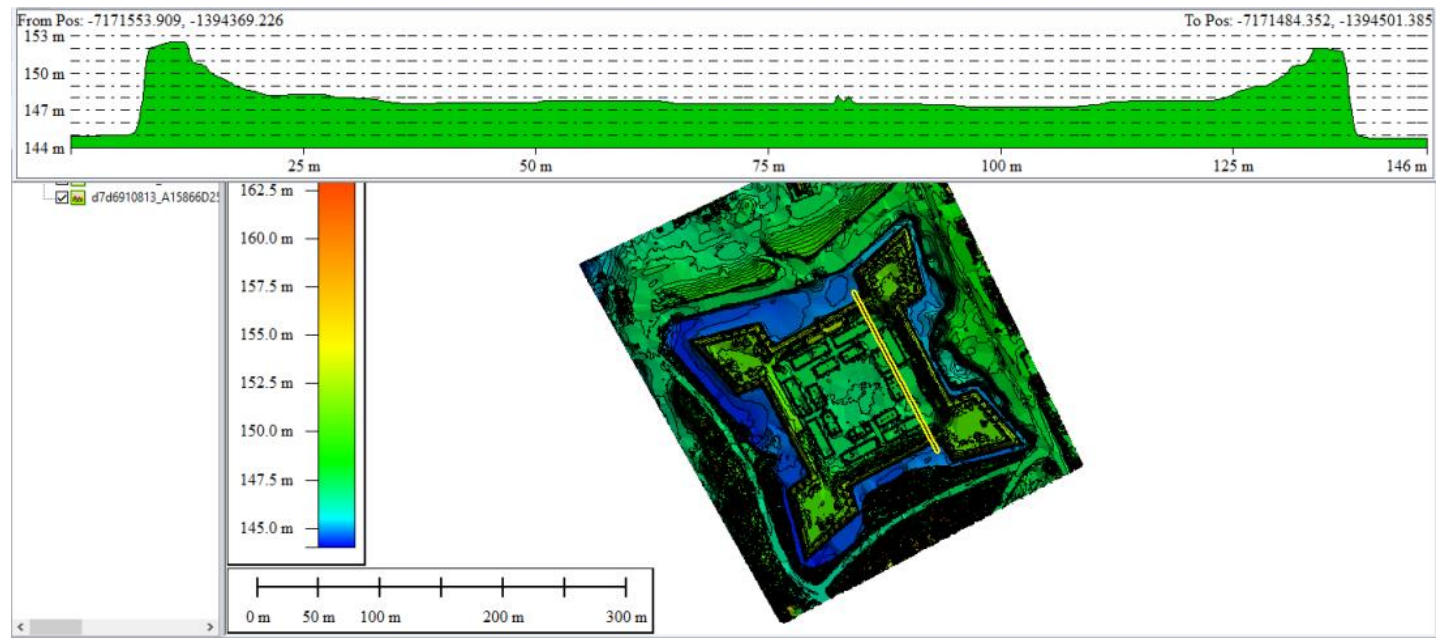

Figura 11: Neste ponto ambas as cortinas preservaram seus parapeitos, mas a inexistência de contramuralhas em ambas as cortinas permitiu que grande parte do reparo do terrapleno fossa arrastado, com a fuga de material. Fonte: Arqueolog Pesquisas 2020.

Esta prática pode ser utilizada para cada ponto que se queira analisar, identificando os pontos de discrepância com os perfis naturais de uma fortificação, apontando os pontos de ausência de estruturas necessárias.

A proposta elaborada pelo arquiteto português Vianna de Lima, da Fundação Calouste Gulbenkian (que estudou o Forte entre 1983 a 1985), já chamava a atenção para os riscos de desmoronamentos do terrapleno, bem como das infiltrações, sobretudo na abóboda do trânsito. Quanto às ruínas das edificações na praça de armas, assume que deveriam ser restauradas (pelo menos parte delas). Considerou ainda não apenas o corpo do Forte em si, mas ainda a estrutura do forno que lhe fica próximo. 
Embora não tenha sido executada, aquela Proposta é bastante considerada, à exceção de alguns pontos, mormente quanto ao monumento que seria construído.

Mais recentemente, pelo menos duas experiências foram postas em prática pelo Iphan, para preservação do Forte. A primeira, emergencial, no sentido de conter o processo de deterioração, de desmoronamento, com o escoramento das paredes, enquanto se busca uma solução mais duradoura. A segunda, aplicada experimentalmente na área do conjunto que envolve o acesso à poterna e as latrinas. Ali, após a realização da pesquisa arqueológica, as estruturas foram remontadas e consolidadas, recuperando praticamente suas condições de uso.

Do nosso ponto de vista, esta se mostrou uma experiência exitosa. O esforço dispendido para esta recuperação nos parece compatível com o respeito para com seus construtores, no sentido de manter em condições de uso tamanha estrutura.

Do ponto de vista técnico, diferentes fontes permitem embasar-se a restauração do Forte nestes moldes. Desde dados históricos, às bases cartográficas que apontam o progresso alcançado nas obras. Ademais, fontes iconográficas permitem conhecer-se muitos detalhes da obra realizada. Complementarmente, mas não menos importante, as pesquisas arqueológicas realizadas e a realizar permitem chegar a detalhes não apenas da construção como de uso e de funcionamento dos equipamentos. Tendo como base sua abordagem material, o estudo arqueológico inclui ainda a possibilidade de integrar outros equipamentos que possibilitaram a própria construção do Bem. Estruturas relacionadas à aquisição, manufatura, transporte das diferentes matérias-primas utilizadas.

Este aspecto de interesse arqueológico diz respeito ao uso de materiais de construção, suas origens, uso ao longo do tempo de construção e destinação final. Quanto às origens, de todo o material empregado, o maior volume é representado pelas pedras que constituem as muralhas, as paredes e suas bases e até mesmo os merlões, que comumente são construídos em tijolos.

Dentre a pedras utilizadas, há que se diferenciar aquelas aplicadas em sua forma bruta ou melhor, irregulares, e aquelas mais trabalhadas, seja nos cunhais, na portada, no conjunto das molduras de portas e janelas, no revestimento das muralhas, e demais detalhes construtivos, incluindo mesmo pisos de alguns cômodos, como é o caso do trânsito (Figura 12). 


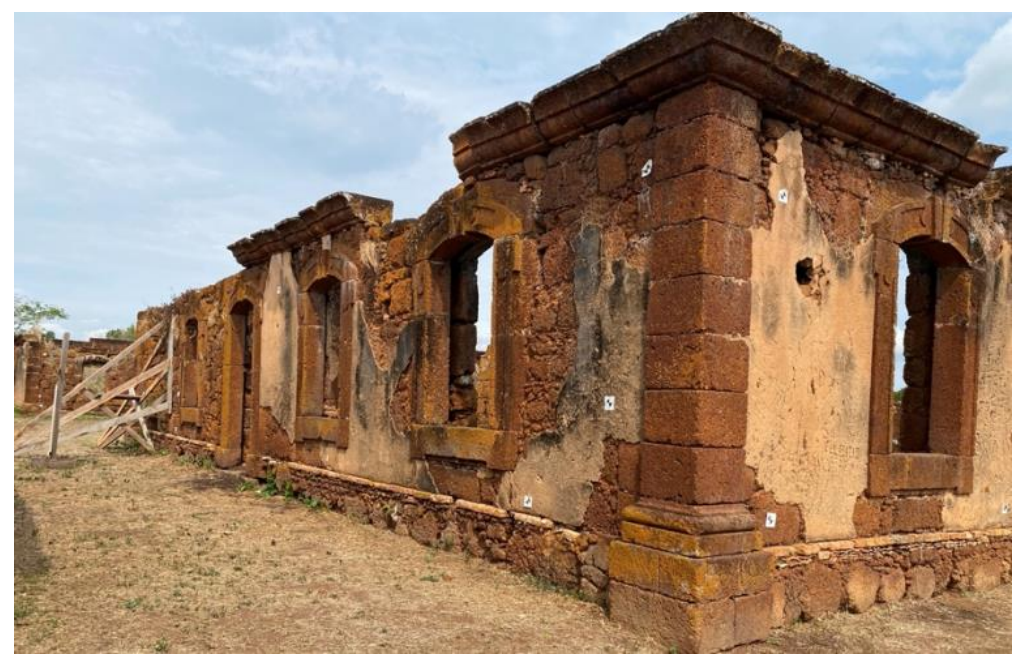

Figura 12: Uso de pedras na construção das edificações internas do Forte. Fonte: Arqueolog Pesquisas 2020.

Embora se tenha levantado alguns indícios e algumas hipóteses, acerca da fonte ou fontes da principal (de maior volume) matéria-prima utilizada, as pedras, parece não estar ainda bem documentada sua procedência. Provavelmente parte das pedras utilizadas foi obtida com a escavação do fosso, como foi comentado por seus próprios construtores.

A formação geológica do local, como se pode ver no corte do terreno aberto para a escavação do fosso, apresenta, há poucos centímetros abaixo da superfície, um manto rochoso., de origem sedimentar, que macroscopicamente corresponde ao material utilizado na construção das paredes rebocadas das edificações internas do forte; pedras brutas, cortadas e sem maior aparelhamento.

Todavia, o corte, mesmo das pedras não trabalhadas deixaria resíduos, fragmentos menores, nem todos aproveitados na construção das paredes. Localizar-se os pontos onde houvesse remanescentes do corte das pedras, seria um importante elemento para confirmar as fontes utilizadas, sua distância e modo de transporte. Em particular o local com restos do trabalho de cantaria.

Há que se considerar, entretanto, que este material de descarte poderia ter sido utilizado no reparo dos baluartes e terraplenos; inclusive na formação do embasamento do glacis. Esta identificação demandaria uma busca estratigráfica em diferentes pontos que não necessariamente remeteriam à fonte do material (Figura 13). 


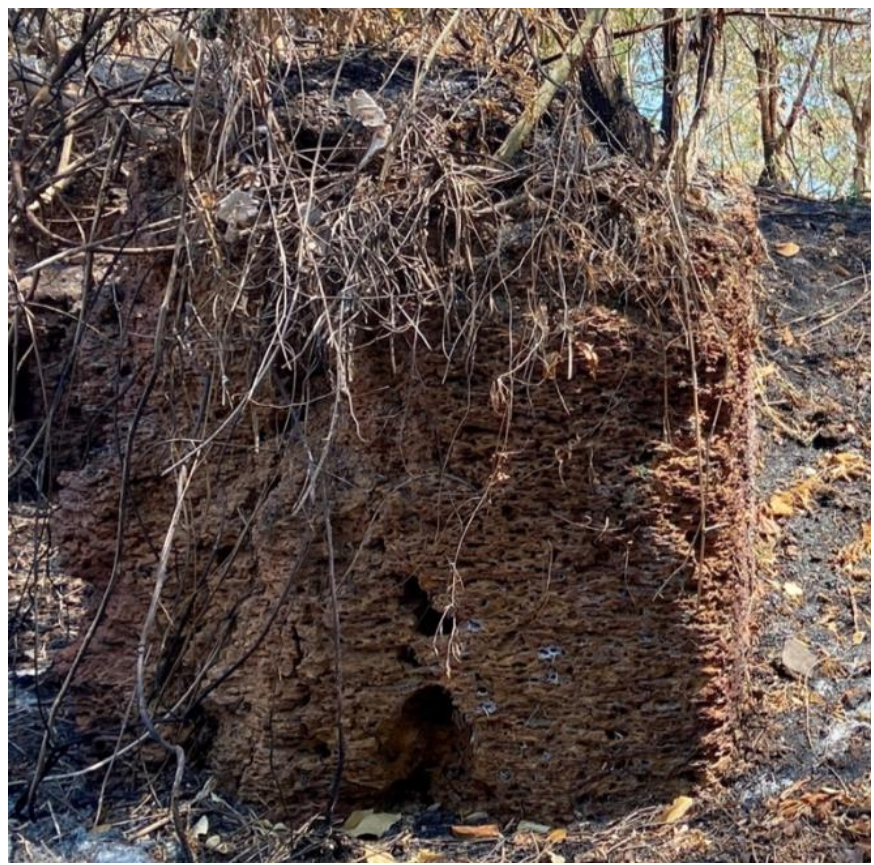

Figura 13: Manto rochoso pouco abaixo da superfície do terreno. (Fonte: Arqueolog Pesquisas 2020).

\section{O Forno}

O forno, por seu turno, envolve forte indícios de associação à construção daquele último Forte construído. Neste sentido temos a considerar o nível de ocupação da área que justificasse a instalação de um forno daquelas dimensões. Outro aspecto a considerar é a técnica de construção de suas paredes, o material empregado, que em muito se assemelham com as práticas adotadas na construção do Forte. Sua proximidade é outro fator a se considerar. Construído no início de uma barranca, seu topo atinge a altura do solo, o que facilita a alimentação do material a ser calcinado, através da parte superior, enquanto, a alimentação com a lenha e a saída das cinzas se daria pela entrada inferior, cuja posição no terreno seria também favorável ao serviço. Uma espécie da banqueta disposta ao longo da parede lateral, define a altura da "grelha" sob a qual circulava o calor proveniente da queima da lenha. Sobre a grelha era depositado o material a ser queimado. Diferentes tipos de grelha poderiam ser utilizados; mais comumente se usa um engradado de tijolos ou mesmo de pedras, vasado, que permite a circulação do calor.

Diferentemente de fornos utilizados para a confecção de cerâmica, os fornos de cal têm o topo aberto, sem a finalização com abóbada. Isto atende sobretudo à forma de abastecimento, com as pedras calcárias sendo depositadas por cima. Durante a queima o topo do forno é 
parcialmente fechado com telhas, ou tijolos, dispostos diretamente sobre as pedras, apenas para preservar o calor, sem criar uma atmosfera redutora, no interior do forno.

Todavia existem referências explicitas quanto a trazida da cal (provavelmente já hidratada) de Cuiabá, de Belém e posteriormente do Registro do Jauru ${ }^{14}$. Todavia, a partir de 1872, a cal teria sido produzida localmente: "A cal empregada na construção fora enviada de Corumbá pela via fluvial do Jauru e dali à do rio Guaporé; só em 1782 foram conduzidas pedras que deram para o fabrico de 2.000 alqueires [de cal]." ${ }^{15}$

Outro aspecto a se considerar quanto à topografia da situação do forno, é a disponibilidade de uma área plana contígua, que permitiria a instalação de uma olaria, por exemplo, caso se tratasse de um forno para queima de tijolos e telhas. Até o momento não temos informações acerca de estudos envolvendo a construção e o modo de abastecimento e de fechamento do forno e sequer acerca de seu uso se para a queima da cal, se para a queima de tijolos e telhas. A identificação das áreas de rejeito ou mesmo do borralho seria muito útil para elucidar tais questões. Este é um aspecto a se considerar para a sua inclusão em futuras pesquisas.

Na realidade, pelo que pudemos apreender da bibliografia consultada até o momento, não se dispõe de estudos que permitam afirmar-se que se trata de um forno de olaria ou um forno de cal. Todavia, por sua forma, que conduz a se estimar sua forma de abastecimento, a altura de seu corpo cilíndrico, poderia apontar para um forno de cal (Figuras 14 e 15).

14 Deste gênero [cal] vieram do Pará perto de mil alqueires; veio depois de Cuiabá, da Povoação de Albuquerque, e afinal do Registro do Jauru, por ter-se achado, não longe, pedra calcária. Apud Manoel Rodrigues Ferreira, "Nas Selvas Amazônicas, 1961", transcrevendo o Barão de Melgaço.

15 Hiram Reis e Silva. A Terceira Margem - Parte LXXVI Real Forte do Príncipe da Beira - XIII Relatos Pretéritos do Forte Príncipe da Beira Antônio Leôncio Pereira Ferraz (1978) p.2. Bagé, 2020. 


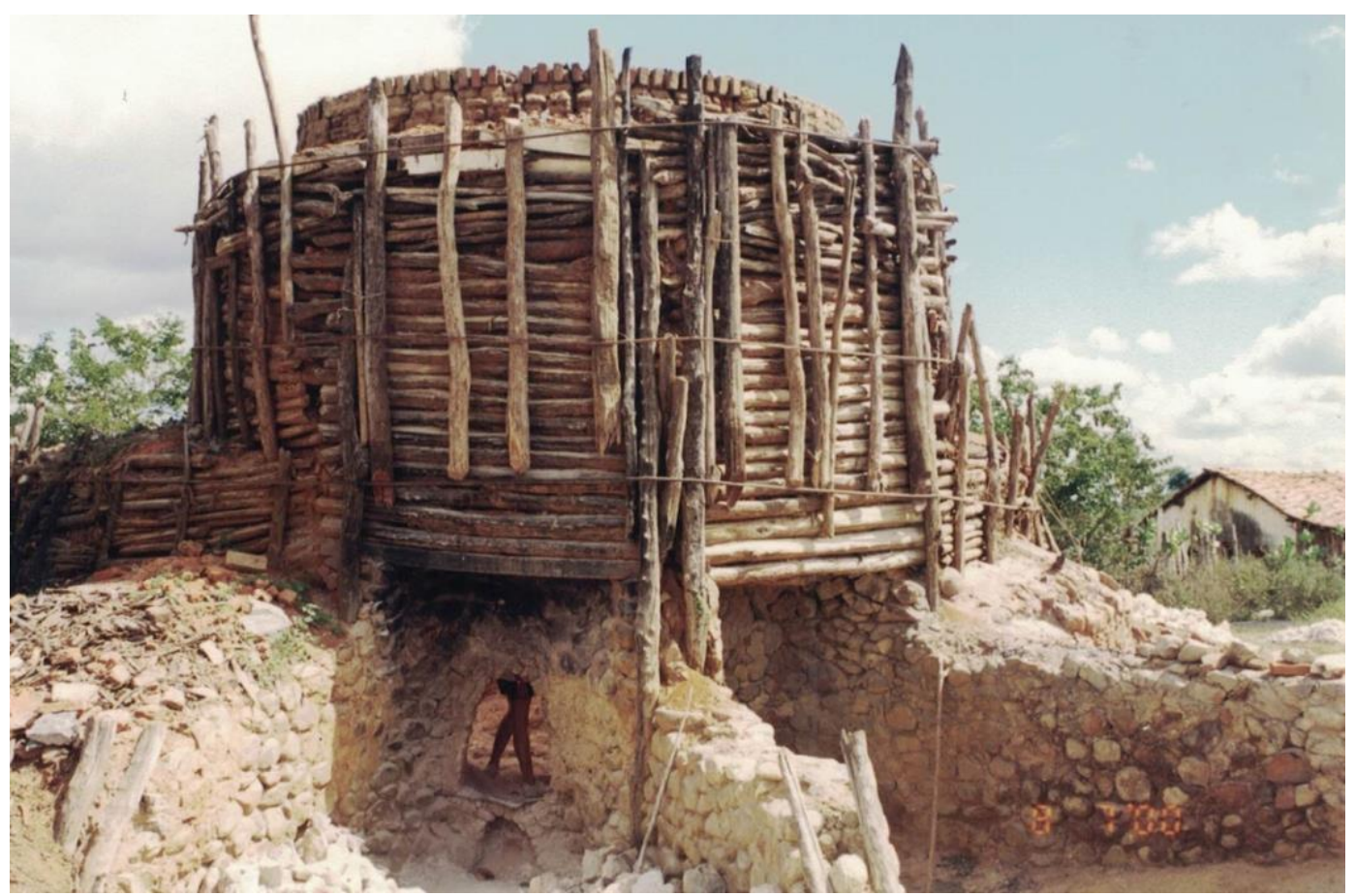

Figura 14: Manto rochoso pouco abaixo da superfície do terreno. Fonte: Arqueolog Pesquisas 2005.

Existem referências ao uso da cal na construção do Forte. Segundo estudos anteriores, o calcário seria oriundo mormente de Belém. Numa área de muitas águas, de chuvas frequentes, seria muito arriscado o transporte da cal "viva" o que remeteria para se buscar aproximar da obra, o local de produção da cal.

Deste modo é lícito se supor que o calcário seria provavelmente calcinado nas imediações da construção, talvez no forno conhecido. Neste caso, seria importante identificar-se também o local do processo posterior, a "queima" da cal, ou seja, o tanque onde a 'cal virgem' seria 'apagada' para poder ser utilizada, ou seja, onde se hidrataria o Oxido de Cálcio (CaO) resultante da "calcinação" do calcário (CaCO3), transformando-o em Hidróxido de Cálcio $(\mathrm{Ca}(\mathrm{OH}) 2)$, a ser utilizado nas argamassas. 


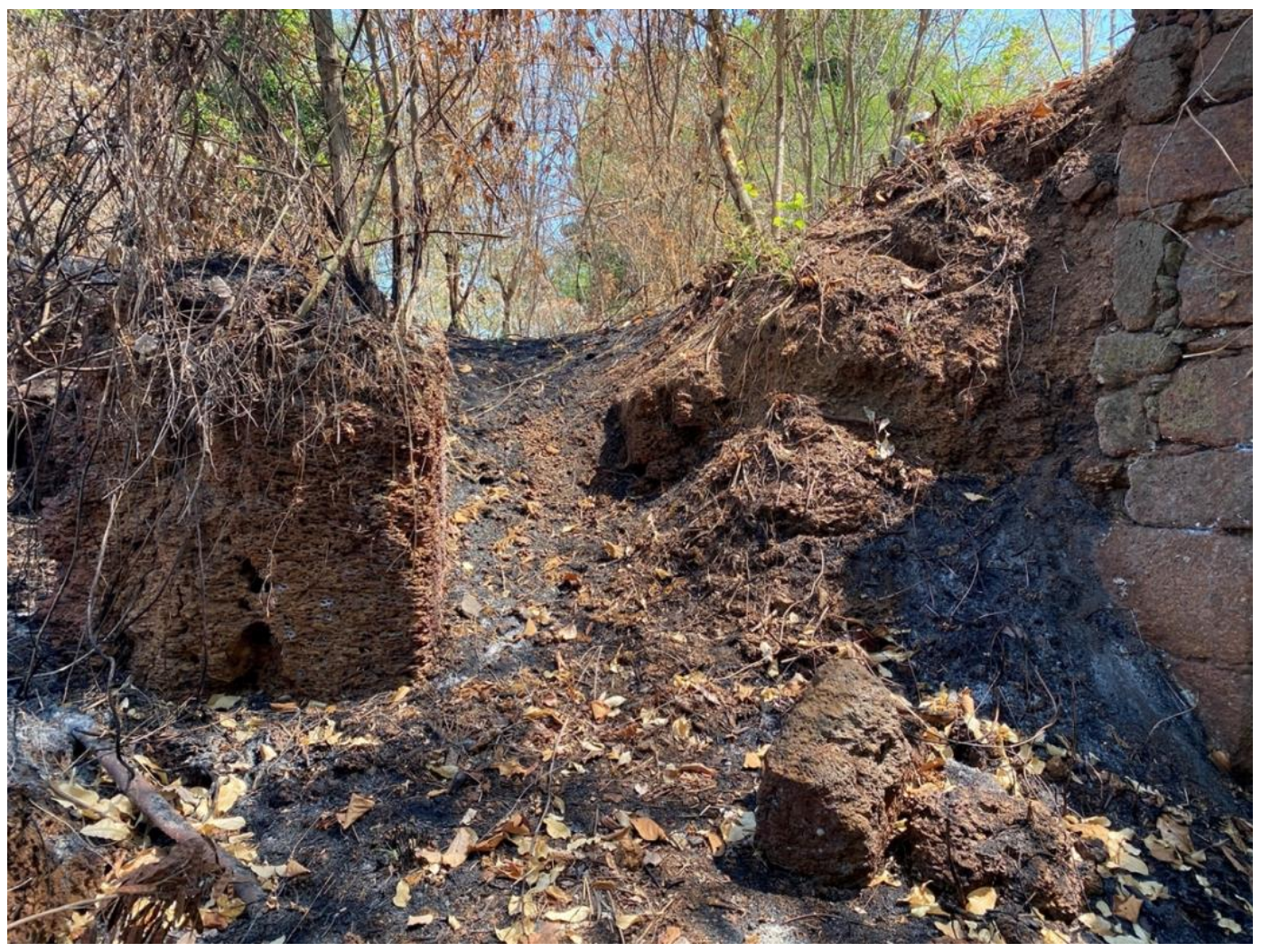

Figura 15: Detalhe do acesso ao forno, observe-se o corte no manto de canga. Fonte: Arqueolog Pesquisas 2020.

Outro aspecto a ser considerado é que, distando cerca de $200 \mathrm{~m}$ do Forte, sua localização refletia uma situação favorável ao transporte, uma vez que naquele trecho a topografia se mostra praticamente plana. Neste aspecto se pode chamar a atenção para a preparação do acesso ao forno, quando o manto de canga foi rigorosamente cortado para permitir uma rampa de acesso entre os níveis superior e inferior na área externa do forno (Figura 16).

O uso do forno para a preparação da cal deveria impregnar as paredes internas, pelo contato com a pedras calcinadas, com pó da cal; ou seja, internamente as paredes ficariam brancas. Não é o que se observa. Todavia, há que se considerar que as muitas chuvas poderiam ter levado consigo muitos dos vestígios. Uma análise comparativa entre o $\mathrm{pH}$ do sedimento no interior do forno e de uma amostra tomada a montante talvez apontasse no sentido de se elucidar a questão.

Com relação ao uso de tijolos e telhas na construção do Forte, a presença de um forno nas proximidades, permite aventar-se a possibilidade de feitura local de tijolos e telhas. 


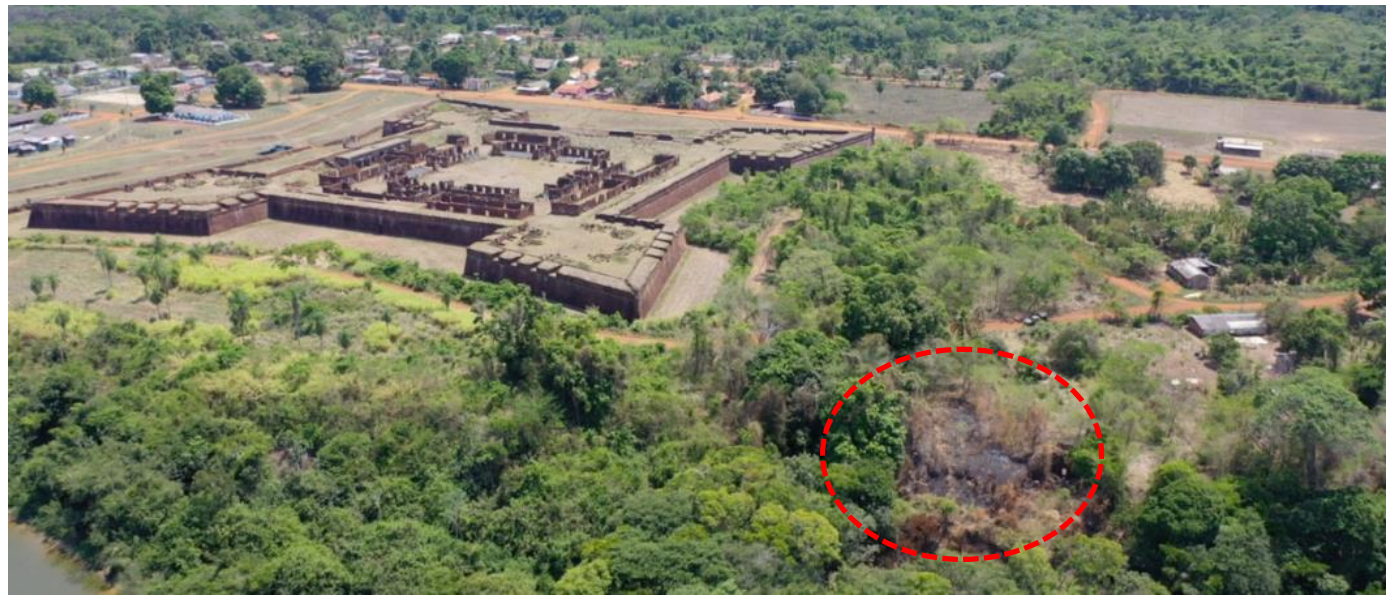

Figura 16: Localização do forno, observe-se sua proximidade em relação ao Forte. Foto: acervo da Arqueolog Pesquisas, 2020

Certamente o maior volume do material construtivo é representado por pedras, todavia o volume de telhas e tijolos é também considerável, o que permite aventar-se a possibilidade de feitura local de tijolos e telhas (Figura 17).

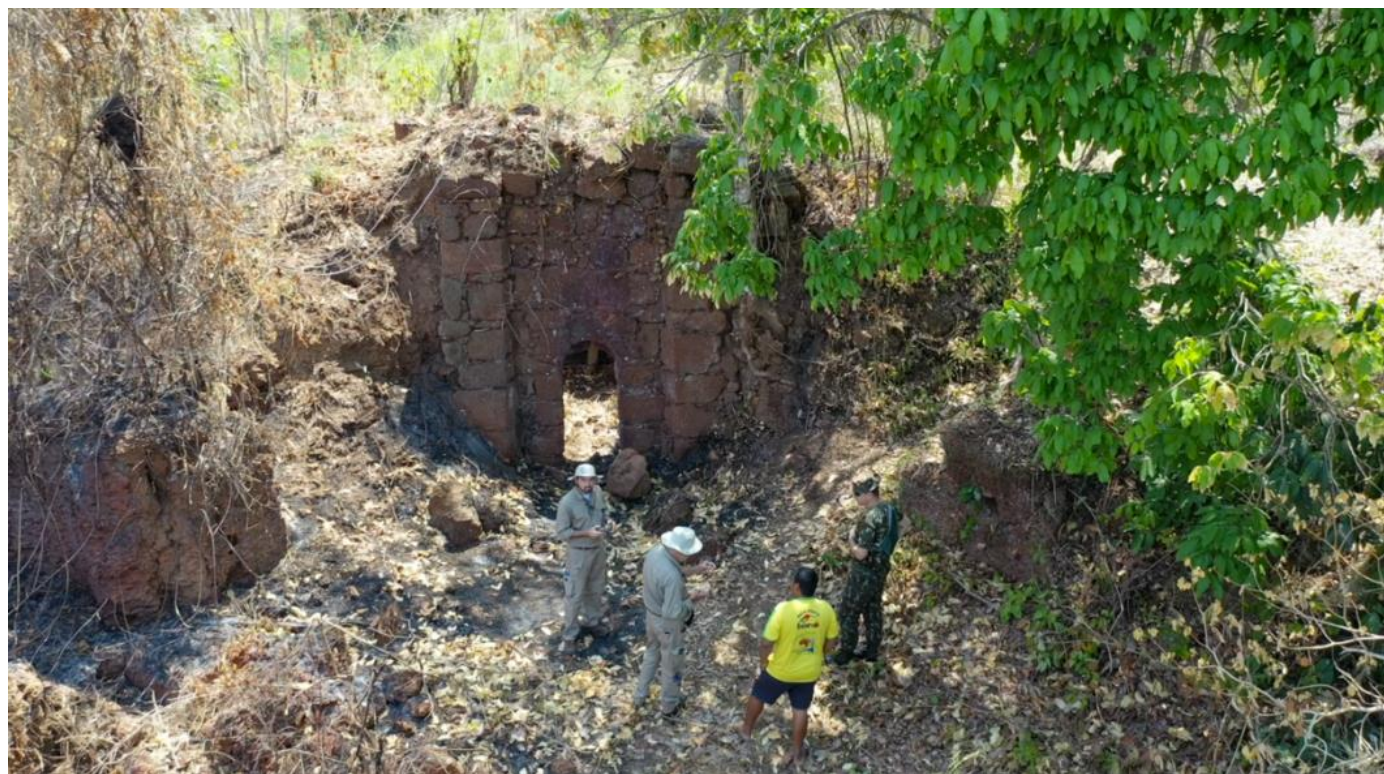

Figura 17: Vista do interior do forno, as pessoas, na área externa, permitem avaliar-se as dimensões. Foto: Acervo Arqueolog Pesquisas, 2020.

Os tijolos, pelo que se pode conhecer até o momento, se restringem praticamente aos pisos da maioria dos cômodos, às abóbadas e ao plano de nivelamento dos alicerces, sobre as quais se erguem as paredes. Certamente um volume muito menor de material, que bem poderia ter sido, ao longo dos anos, queimado no forno conhecido nas proximidades do Forte (Figura 18) 


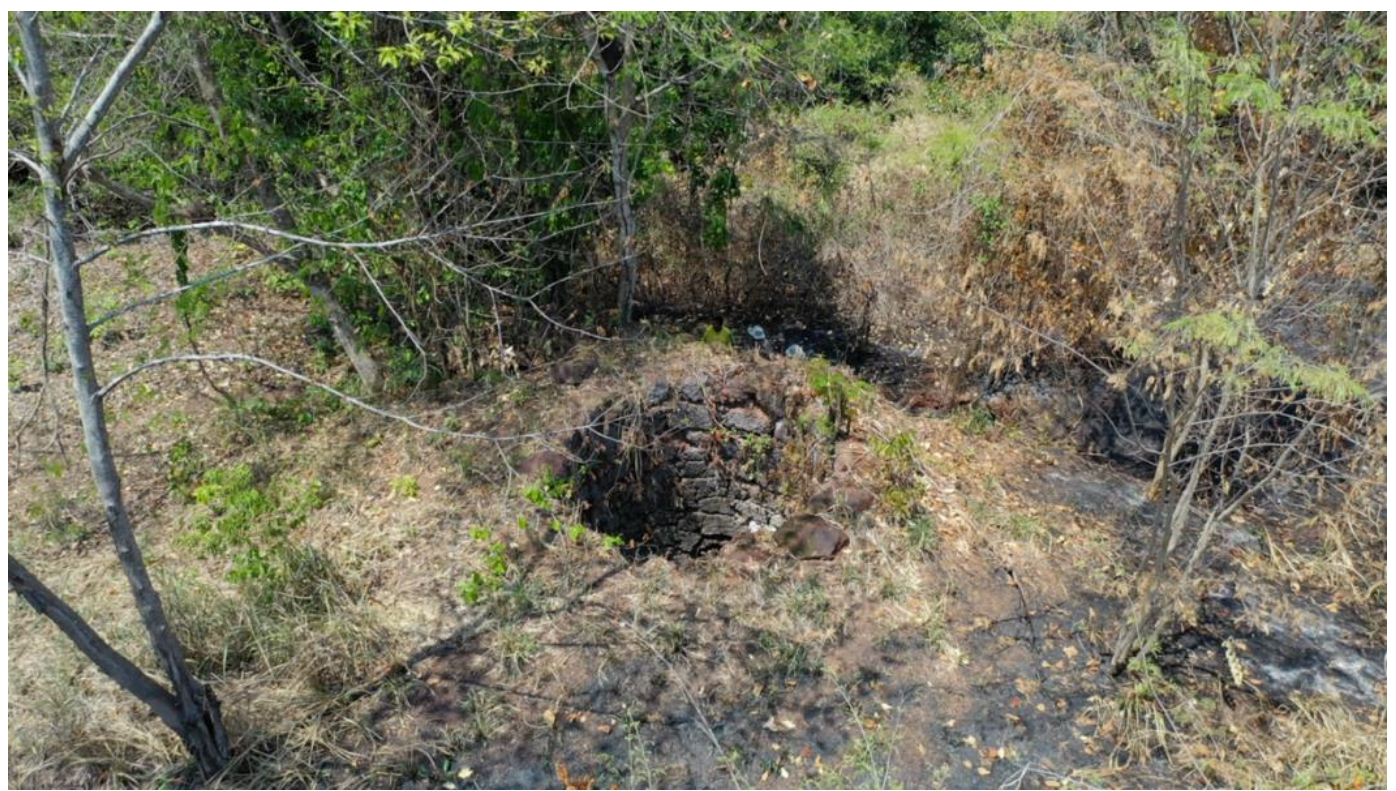

Figura 18: Vista superior do topo do forno. Acervo Arqueolog Pesquisas, 2020

Sob esta ótica, do ponto de vista do entendimento das práticas para a construção do Forte, seria importante um reconhecimento inicial e posteriormente um estudo arqueológico específico no entorno das ruínas do forno, no sentido de localizar-se uma eventual olaria, onde se tivesse moldado os tijolos e telhas a serem queimados no forno.

De qualquer sorte, a identificação da área de refugo, traria, certamente, informações esclarecedoras.

\section{A Casa de Pólvora}

Outro ponto de interesse, sobretudo para uma análise comparativa, são as ruínas da casa de pólvora. A presença das aberturas para ventilação, em sua forma tradicional para casas de pólvora, representa o elemento identificador de sua função, como já comentou Barcelos ${ }^{16}$. Embora tivesse, provavelmente prevista para ser construída no interior da praça, de fato fora construída na área externa às muralhas. Identificar-se o período de sua construção, talvez pudesse esclarecer quanto à decisão de alterar o local previsto. A planta inicial do Real Forte Príncipe da Beira seria da traça do mesmo engenheiro, Domingos Sambucetti, que também projetou o Forte de São José de Macapá, obras praticamente contemporâneas. No Forte de Macapá, construção igualmente monumental, a casa de pólvora foi construída intramuros. Teria o projeto do RFPB sido alterado pelo sucessor do engenheiro, quando de sua morte?

${ }^{16}$ Barcelos Giovani da Silva, 2018. 
Todavia um outro aspecto pode ser levantado, a questão da experiência de seus construtores acerca da amplitude que o nível das águas poderia alcançar. Existe uma referência de que o Real Forte teve a cota de seus alicerces com base no mesmo nível da última enchente (1771), quando derrubou o Nossa Senhora da Conceição".

Embora não tenhamos, no momento, uma medida precisa da cota da porta principal do Forte, podemos considerar que a altitude de sua praça é em torno de $139 \mathrm{~m}$, enquanto a cota da casa de pólvora é da ordem de 159m, ou seja cerca de $20 \mathrm{~m}$ acima (Figura 19).

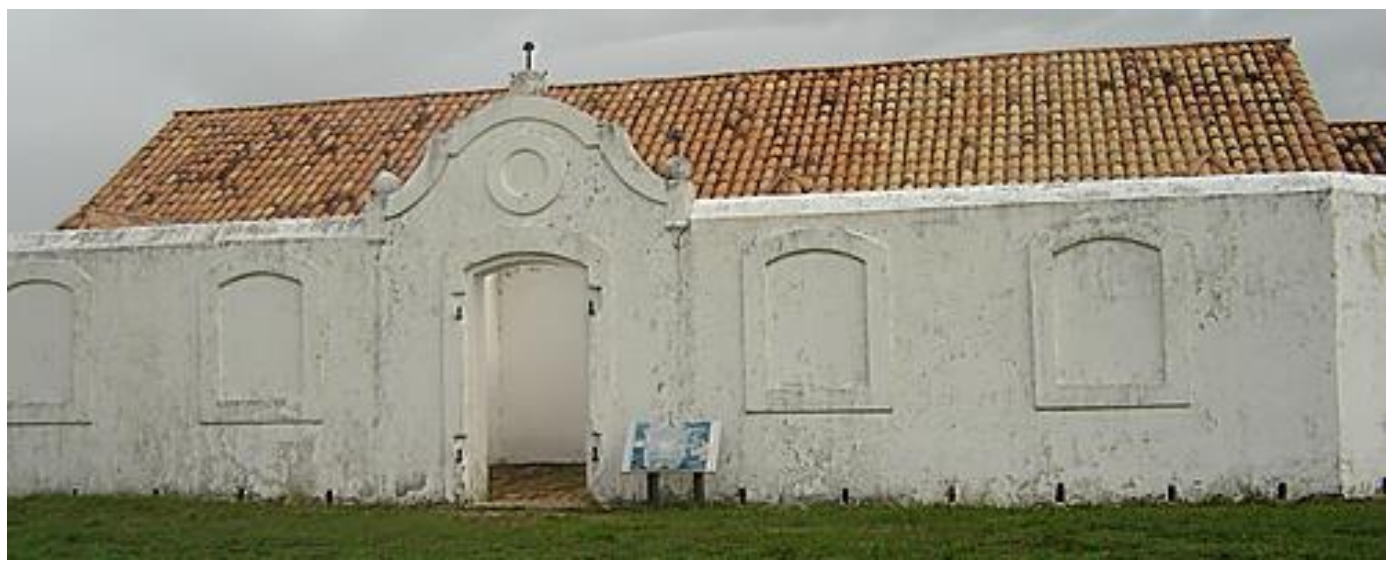

Figura 19: Casa de pólvora do Forte de S. José de Macapá, com suas paredes reforçadas em torno do depósito. Fonte: Acervo Arqueolog Pesquisas, 2019.

Existe uma referência a uma casa de pólvora subterrânea no interior do Forte, mas até o momento não foram resgatadas evidências desta construção.

Defronte deste portão está um rebelim com ponte levadiça, e um famoso fosso, cisterna, casa de pólvora subterrânea, hospitais, armazéns, quartéis para o Governador, e para a guarnição, prisões, e uma Capela decente, sem que algum desses edifícios se veja de fora das muralhas (Cit https:f/www.ecoamazonia.org.br/2020/10fterceira-margem-parte-|xxi p.4).

Todavia provavelmente existiria um depósito de pólvora, ainda que de menores proporções, que garantiria o início de uma defesa. Há que se considerar que, no interior da praça de armas existe um espaço aberto que corresponderia à localização de uma 16a estrutura. Poderia se tratar do local reservado à casa de pólvora não construída, ou ainda uma estrutura subterrânea desativada. Este local poderia ser alvo de uma prospecção arqueológica, seja interventiva ou por métodos geofísicos (Figuras 20 e 21).

A casa de pólvora, além muros, pode se dizer, certamente está associada à estrutura defensiva da área e deve ser preservada e integrar o conjunto tombado. 


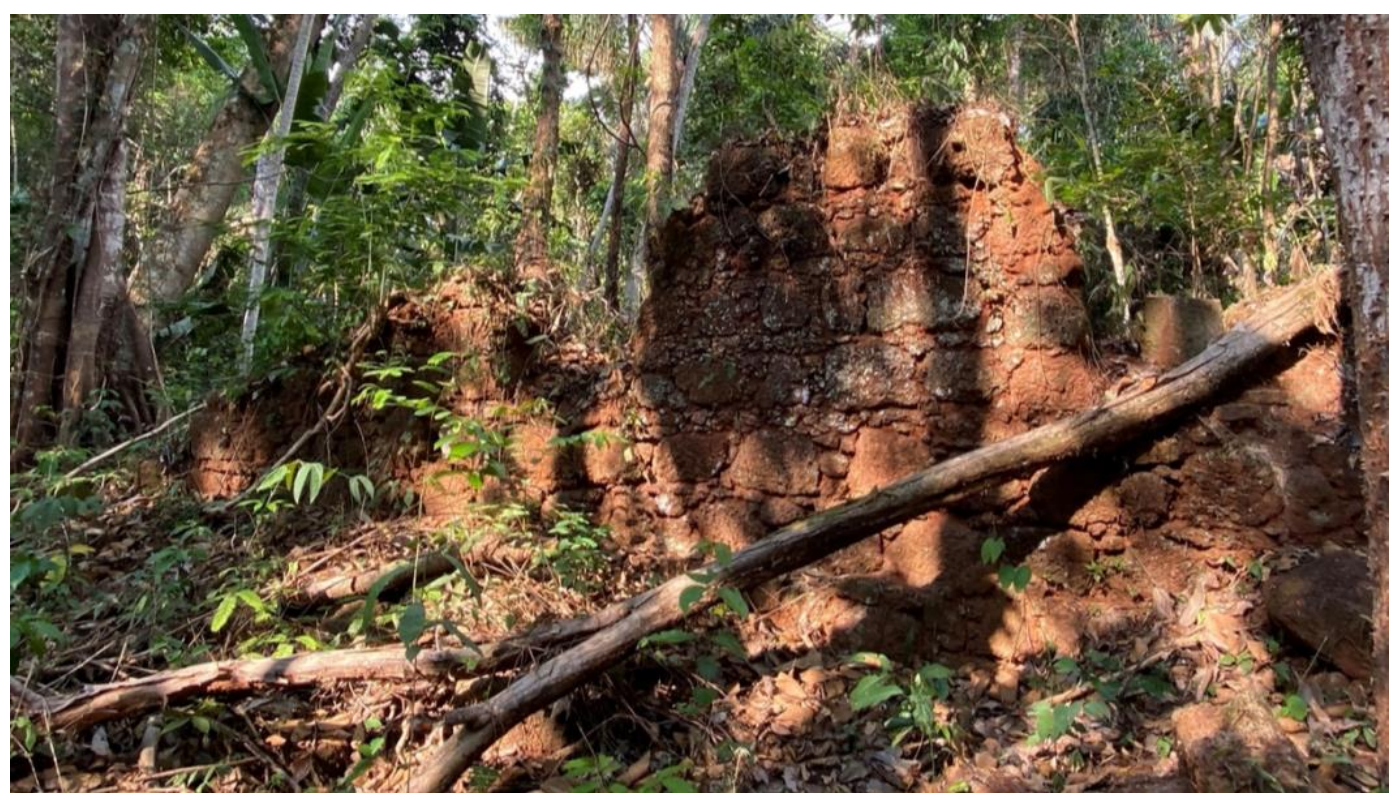

Figura 2: Ruínas da 'casa de pólvora', em meio à mata. Fonte: Arqueolog Pesquisas 2020.

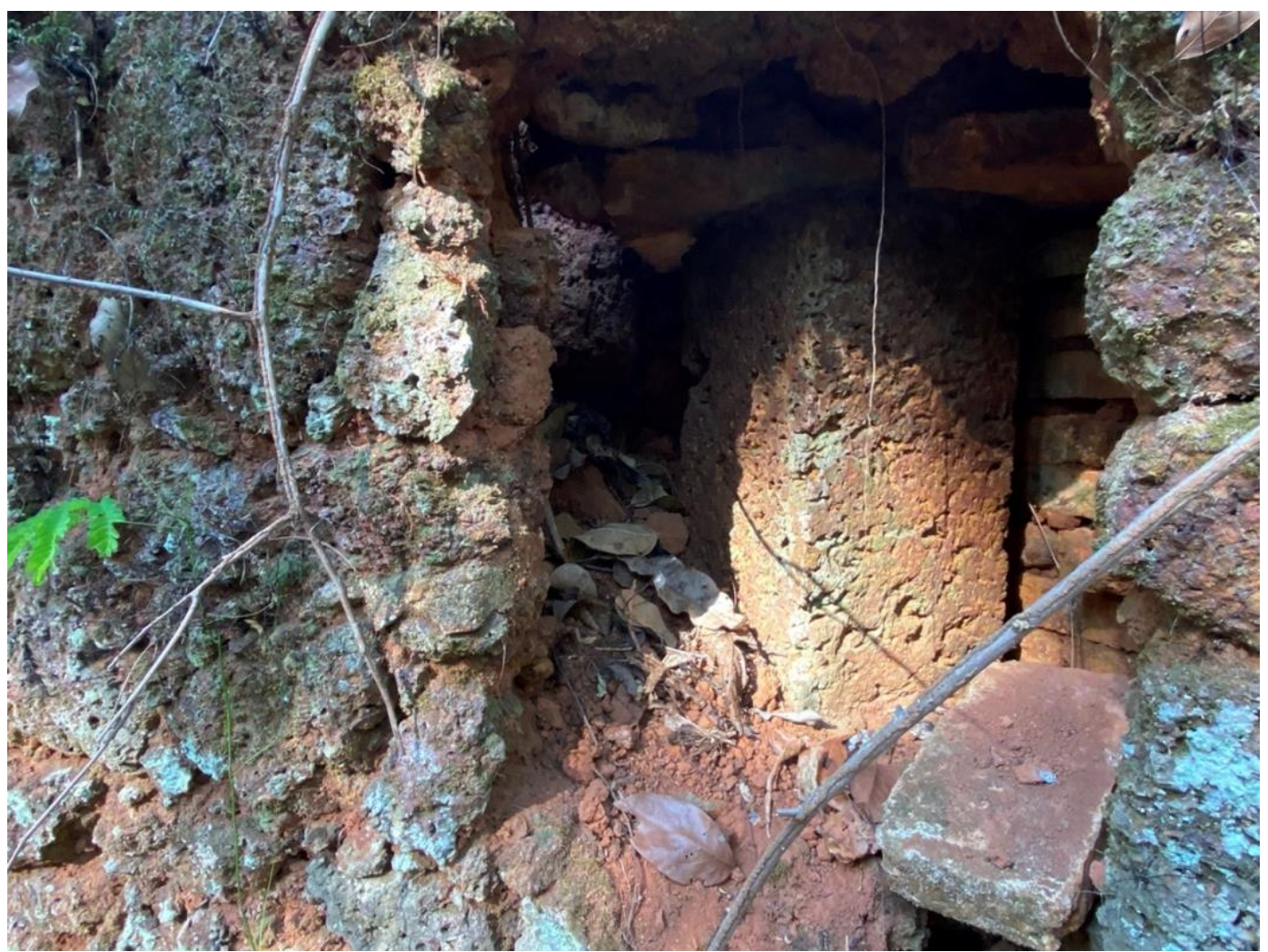

Figura 3: Detalhe da ruína da fresta de ventilação, característica de casas de pólvora. Fonte: Arqueolog Pesquisas 2020.

\section{Outras estruturas não localizadas}

Outro aspecto, ainda sob o prisma da identificação funcional das diferentes edificações, chama a atenção a ausência de pelo menos uma cozinha. Ainda traçando uma comparação com o 
Forte de Macapá, ali se pode registrar a presença de diversas cozinhas (fogões à lenha) presentes em casamatas sob o terrapleno da cortina sudoeste (Figuras 22 e 23 ).

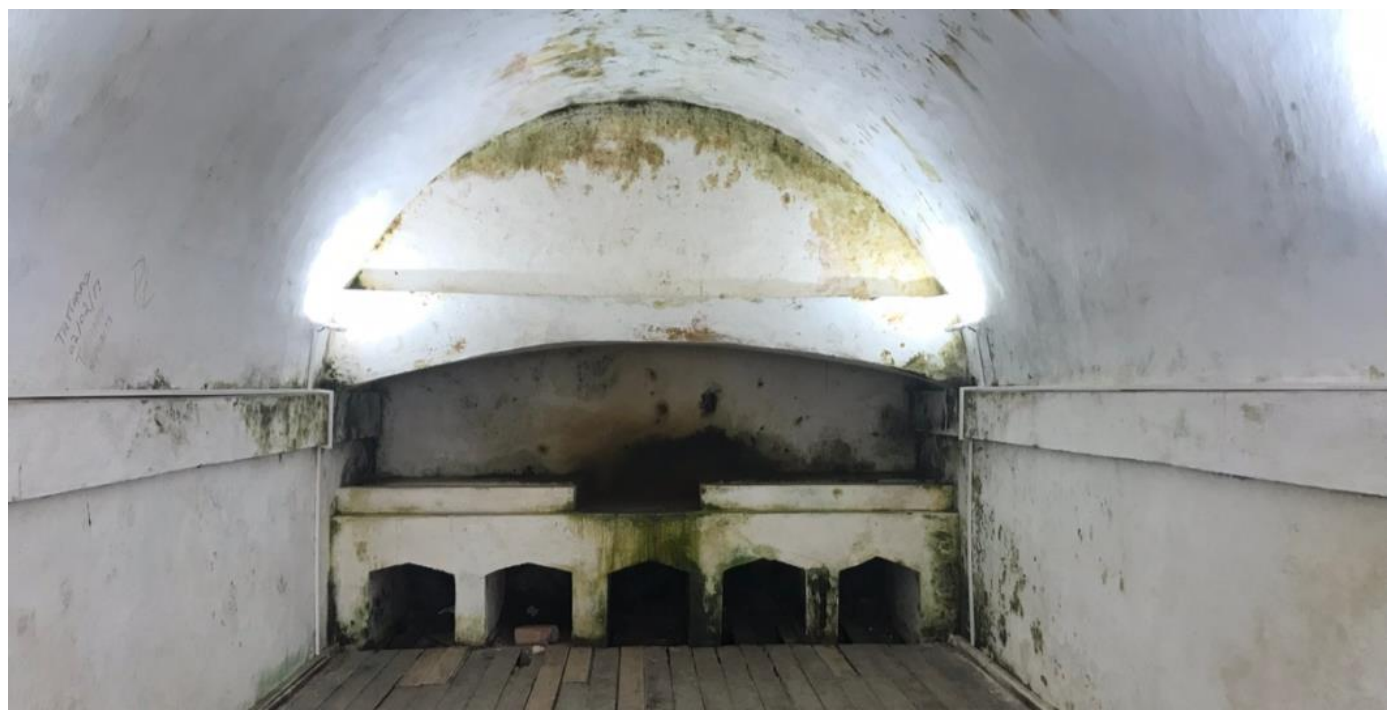

Figura 22: Uma das cozinhas no interior das casamatas, com seus fogões à lenha. Acervo Arqueolog Pesquisas. Fonte: Arqueolog Pesquisas 2019.

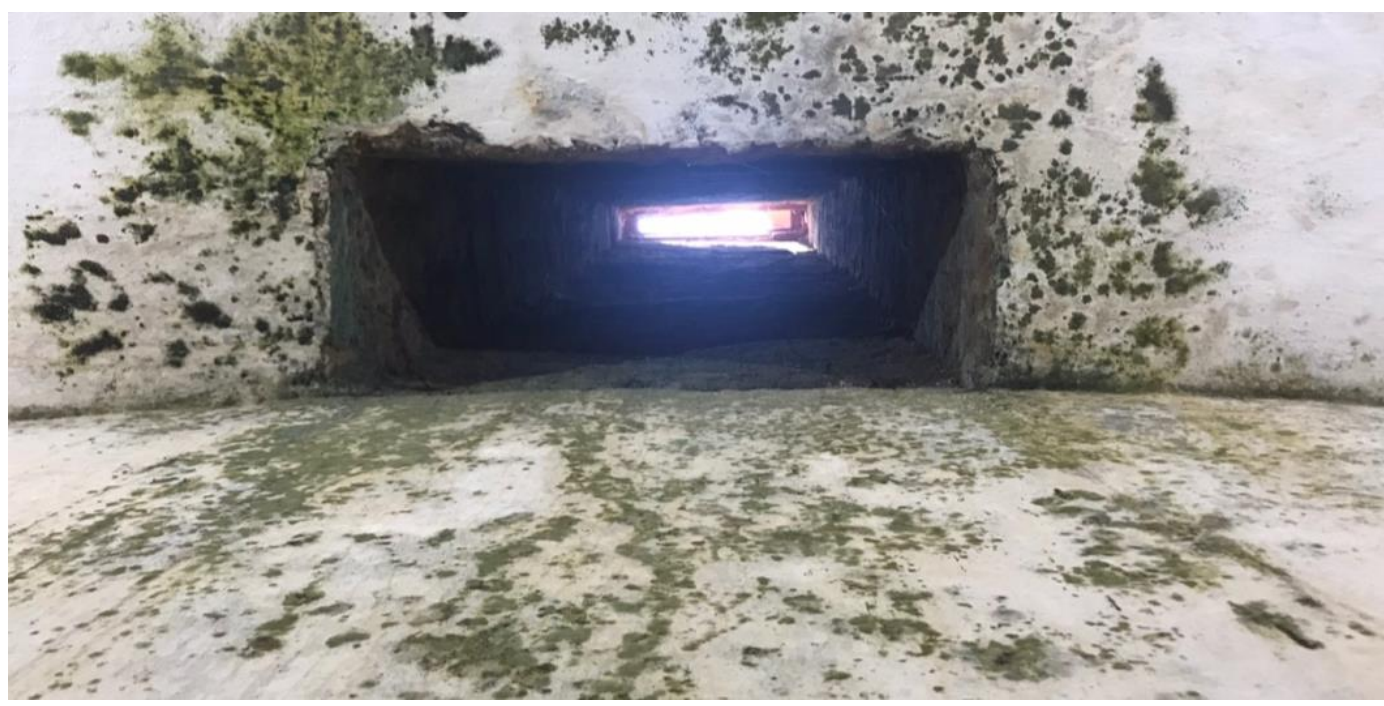

Figura 23: Detalhe da chaminé, na abóbada da casamata. Fonte: Acervo Arqueolog Pesquisas, 2019.

Outro ponto, este convergente, é a presença de um reservatório de água ou estrutura de drenagem, como é também referido, no centro da praça de armas. De fato, não chegamos a estudar a estrutura no centro da praça de armas do Forte de Macapá (nossa pesquisa foi restrita às defesas externas da fortificação). Todavia, pudemos observar que aquela estrutura não se mostra encimada por uma abóbada, como acontece no RFPB. Por outro lado, a cisterna do RFPB, foi analisada pelo Iphan e pelo Prof. Fernando Luiz Tavares Marques, conforme consta de seu Relatório (06/2008), e ainda por Barcelos (2018), que considera: "No centro da praça de armas foi construída uma cisterna em pedra com o objetivo de armazenar a água da 
chuva e utilizá-la na limpeza das duas latrinas existentes ao lado da poterna.". Na realidade o sistema de drenagem do RFPB é complexo, envolvendo pelo que foi descrito, diferentes sistemas que atendem a áreas distintas, como a praça de armas, os terraplenos etc. Uma preocupação compatível com o índice pluviométrico da região. Todavia, considerando a própria complexidade do forte, há que se considerar que no interior da fortificação deveria existir uma fonte ou reservatório de água potável. Tais fontes nem sempre são apontadas nas plantas, mas quase sempre estão presentes, pois se trata de um pré-requisito fundamental.

Com base no perfil apresentado na página 42, em associação com a imagem 1 da Figura 37, do Relatório Arqueológico de 2008, podemos considerar que a estrutura se trata realmente de uma cisterna, desempenhando a função de captação das águas infiltradas no interior da praça de armas (que percolariam até a profundidade de $3,16 \mathrm{~m}$, penetrando na cisterna por entre as pedras naquela profundidade). Todavia, não nos pareceu claro na documentação gráfica e iconográfica se a estrutura de fundo (a 5,42 profundidade) apresenta a base lacrada, funcionando como depósito de água, ou se permite o afluxo de água do lençol freático (uma cacimba ou poço). Um pouco acima (a $2,82 \mathrm{~m}$ de profundidade), a canaleta que se dirige no sentido da poterna e escoa pelas latrinas, serve também para regular o volume da água acumulada, mantendo-a abaixo do nível da abóbada de tijolos - um sangradouro. Este sistema que serviria também como drenagem das águas da praça de armas, teria as águas filtradas através da camada de solo servindo ao abastecimento do Forte. Com seus 4,4m de diâmetro maior (apenas 0,34m abaixo do sangradouro), um reservatório ponderável.

\section{0 'Labirinto'}

Trata-se de um conjunto de estruturas em pedras, sobrepostas, que formam extensos 'muros de pedras' cuja altura excede 2,5m. Apresentam-se muitas vezes em paralelo, formando como que um extenso corredor. Todavia, sua distribuição no espaço não pode ainda ser efetivamente levantada. Alguns esboços foram ensaiados com a captura de pontos de GPS em parte de seu traçado, o que se mostra inteiramente insuficiente para definir-se sua forma e distribuição, dados essenciais para se buscar a identificação.

Atualmente, a área é coberta pela mata, o que não permite a captura de imagens aéreas com câmeras comuns. O processo que nos parece mais adequado no momento seria a captura de imagens aéreas com o Lidar, com feixes de laser adequados à penetração na massa verde da 
área. Diversas hipóteses têm sido levantadas, buscando identificar/explicar tais estruturas. Hipóteses que variam desde possíveis conexões com grupos andinos a depósitos de material de construção, trazidos para as obras do Forte.

Esta última hipótese tem sido considerada por pesquisadores de Belém (informação oral da Dra. Roseane Norat) que identificaram a presença de estrutura similar às margens do rio Pedreiras, no Amapá17, e que bem poderia ter servido à construção do Forte de Macapá, do mesmo período (Figuras 24).

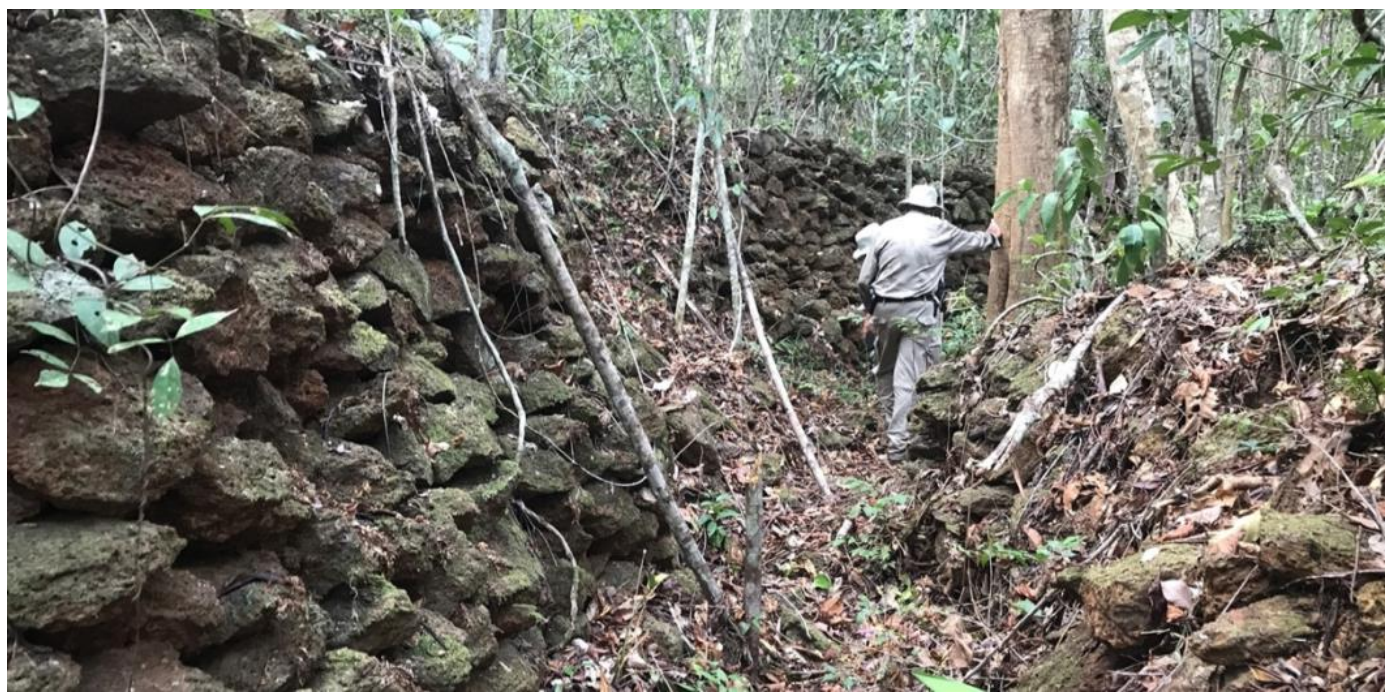

Figura 24: Trecho do labirinto onde se pode observas paredões de cada um dos lados do caminho. Observe-a a altura em relação a uma pessoa de 1,80m. Fonte: Arqueolog Pesquisas 2020.

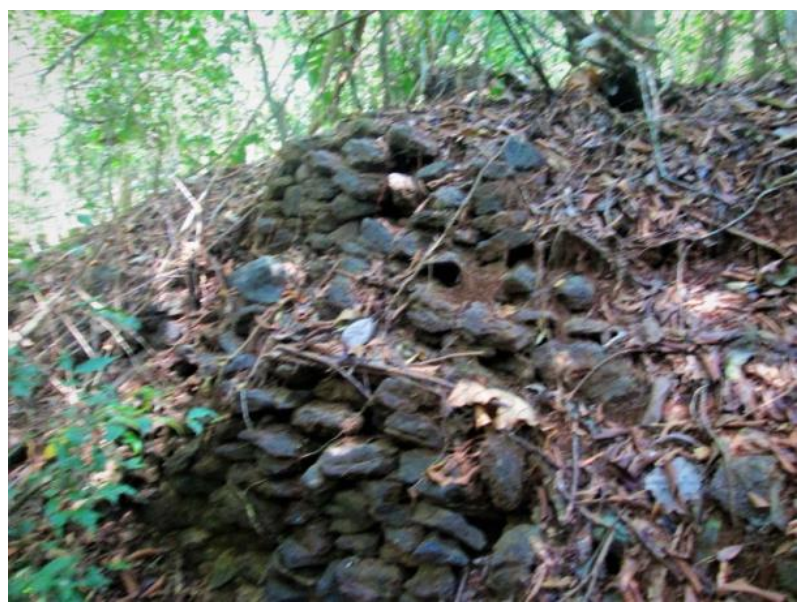

Figura 25: Trecho do 'labirinto' nas proximidades do Rio Pedreira, no Amapá. Foto do acervo de Roseane Norat, 2018.

${ }_{17}$ Norat, R. da C. C. ; Da Costa, M. L. Characterization, usage and provenance of building rocks in the Fortress of São José of Macapá (Amazon, Brazil). Engineering Geology, v. 253, p. 214-228, 2019. 
Ambas as estruturas se encontram próximas a rios que poderiam constituir-se em ponto de embarque ou de desembarque do material, para transporte até as respectivas obras. Todavia a forma de arrumação das pedras, sua distribuição no espaço, pelo pouco que se pode perceber em meio à mata, parece não apontar pra uma forma prática de deposição para um ponto de "bota e tira" de obras. Exemplo disso é a altura atingida pelos muros, que exigiria uma estrutura de apoio, construída para colocar-se ou retirarem-se as pedras. Outro aspecto que pode ser observado é a disposição praticamente vertical, diria mesmo à prumo, de alguns daqueles muros de pedras não argamassadas. Não nos parece se tratar de um conjunto de pedras depositadas a ermo, para serem posteriormente transportadas. Antes sugere se tratar de uma construção. Assemelha-se inclusive às chamadas 'cercas de pedra' tão comuns nos sertões do Nordeste. Certamente diferem em altura, mas certamente aproximam-se na feitura (Figura 26).

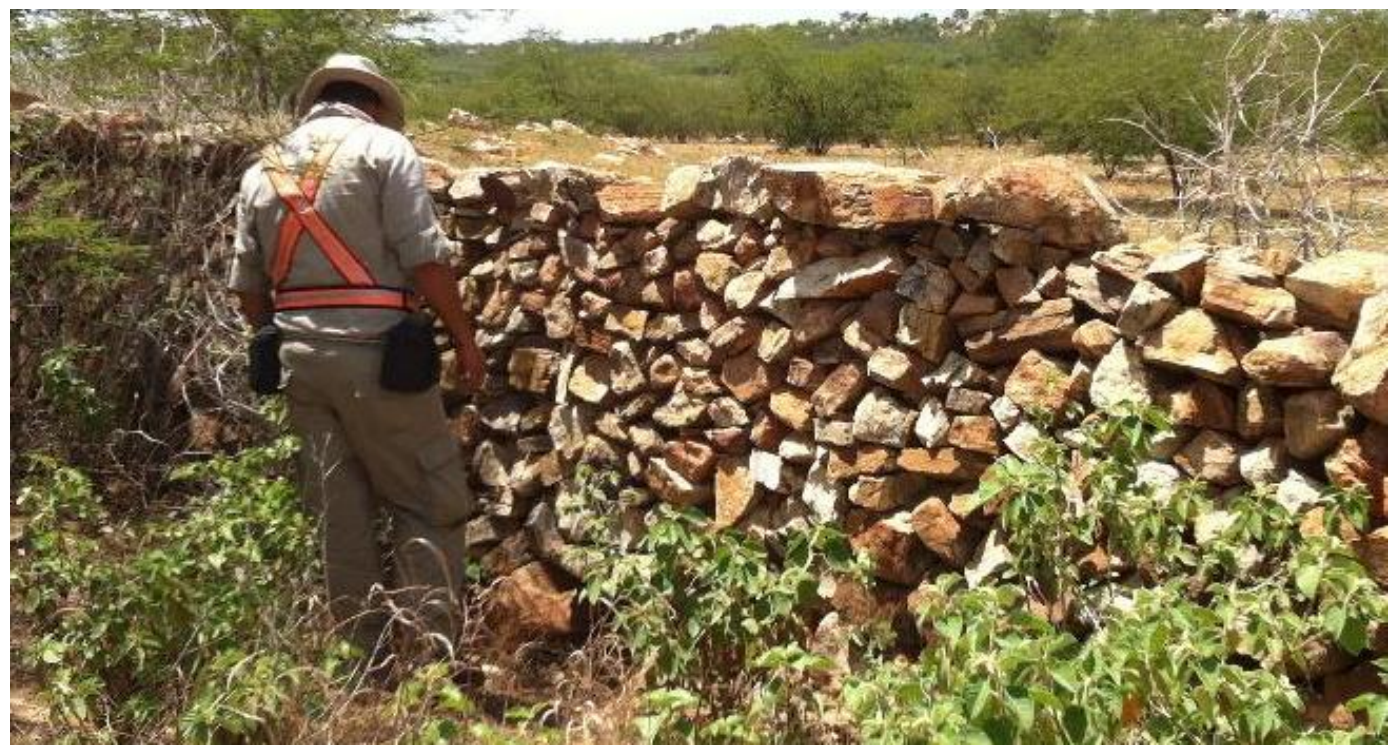

Figura 26: Cerca de pedra no interior da Paraíba. (Fonte: Arqueolog Pesquisas 2013).

Neste mesmo sentido, o historiador Lourismar Barroso traça uma argumentação com base em relatos históricos, que o conduziram a associar as estruturas do 'labirinto', à antiga Missão de Santa Rosa Velha:

O 'labirinto' que os moradores da localidade descobriram e, insistem em manter vivo o termo, foi, na verdade, conforme Manuel Rodrigues Ferreira a Missão de Santa Rosa Velha, criado pelo Padre Atanásio Teodori 17 em 1743, à margem direita do Rio Guaporé, aldeando dezenas de tribos indígenas do lado espanhol. 
A argumentação apresentada encontra convergências quando se observa a presença em meio aos paredões, de construções que bem poderia se tratar de um abrigo (casa?), como o que se vê na Figura.

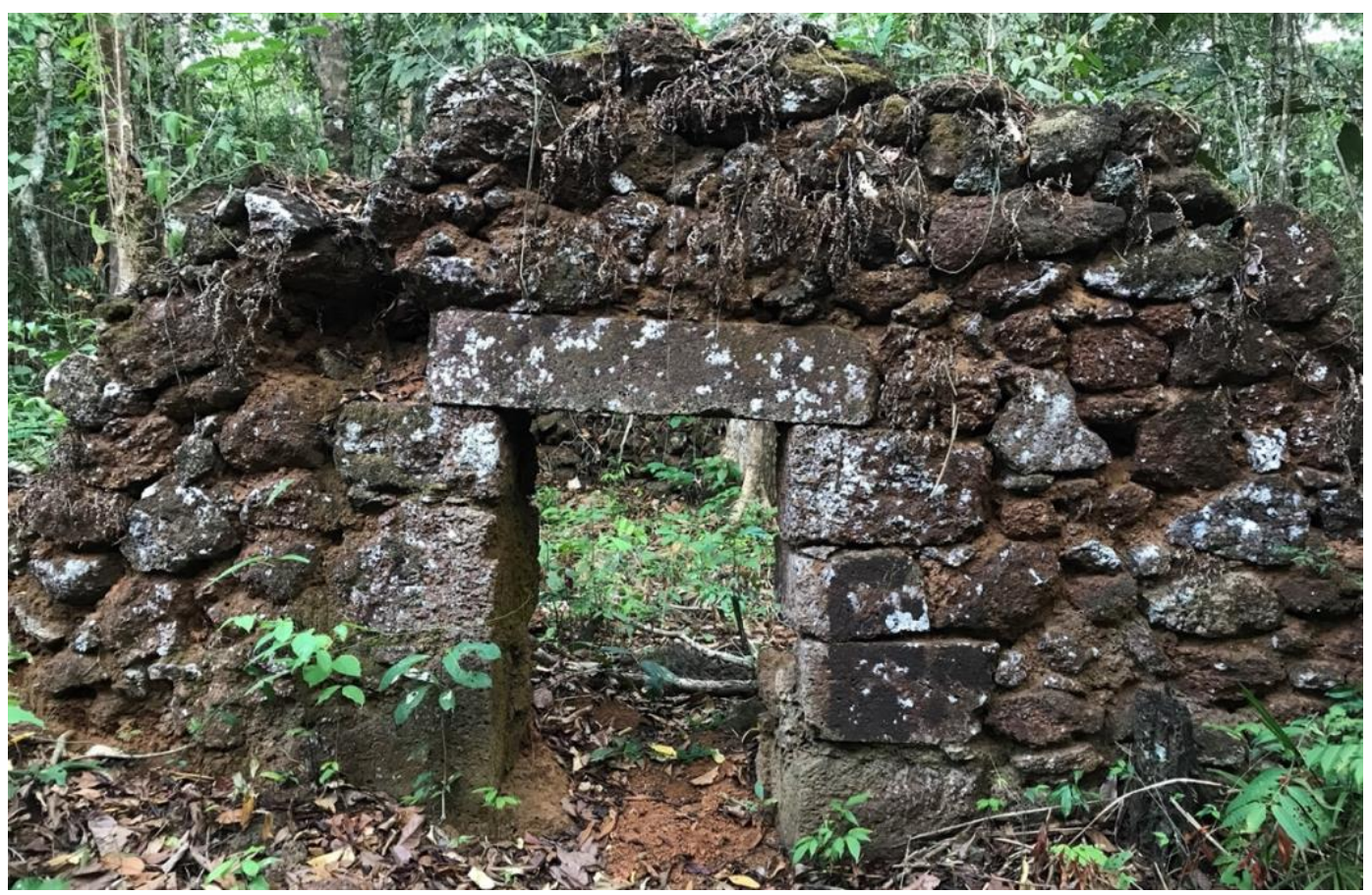

Figura 27: Construção que se encontra em meio às paredes do 'labirinto'. (Fonte: Arqueolog Pesquisas 2020).

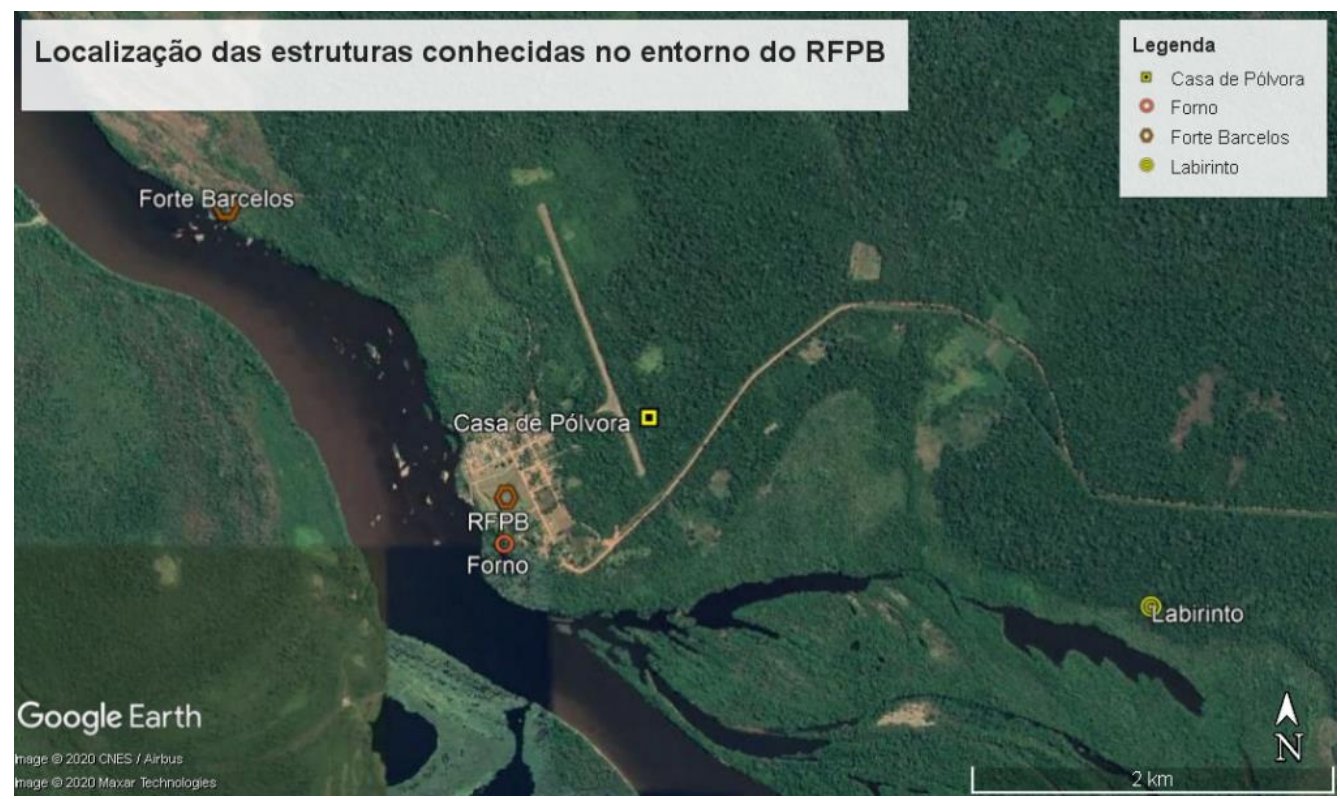

Figura 28: Localização das estruturas conhecidas em torno do RFPB. Google Earth, 2020 


\section{Considerações Finais e sugestões}

Proposições de estudos complementares a serem realizados: Elementos básicos a serem buscados (estruturas)

Inicialmente recomendamos fortemente a atualização do 'mapa de danos' e sua comparação com versões anteriores, de modo a identificar aquelas áreas onde a dinâmica da desconstrução se apresenta mais ativa, de maiores riscos, carecendo de ações imediatas. Aplica-se tanto a estruturas internas quanto às muralhas e contramuralhas, e ainda às obras externas, em particular o caminho coberto e sua banqueta e esplanada. Esta avaliação permitirá estabelecer-se as áreas prioritárias para intervenção e quiçá adotar-se medidas preventivas que interrompam eventuais processos de danos.

As proposições de estudos aqui apresentadas, ainda sob uma ótica horizontal, reúnem aspectos de interesse arqueológico, direto e indireto, que podem já ter sido tratados por outros autores que não tenhamos tido acesso, face à exiguidade de tempo para atender a VOT.

Tais estudos se voltam tanto a questões intrínsecas às estruturas do corpo da fortificação, quanto a questões relativas à forma, ao modo de fazer daqueles que se envolveram com a sua construção. Assim, entendemos que do ponto de vista das fontes materiais, a identificação de algumas áreas de produção, naquele entorno, seria certamente reveladora do cotidiano daqueles que se envolveram diretamente com as obras. Neste sentido podemos considerar estudos em áreas específicas, conhecidas, e estudos prospectivos que trariam oportunidade de identificar-se novas áreas a serem abordadas.

Dentre as áreas específicas, podemos sugerir aquelas no interior do corpo da fortificação e em sua área externa:

\section{No interior da fortificação}

Sistema de abastecimento da cisterna, se apenas percolação ou se inclui o aproveitamento do aquífero. Neste sentido envolveria questões relacionadas ao volume de água disponível na estação das águas e na estação seca; incluindo velocidade de recuperação; e qualidade da água em relação à potabilidade e salubridade. 
Busca por eventuais vestígios de uma 16a estrutura interna, assinalada em plantas. Esta área que se constitui, na atualidade, em um espaço vazio poderia ser alvo de uma prospecção arqueológica, seja interventiva ou por métodos geofísicos. No caso de serem identificadas estruturas abaixo da superfície, se empreenderia uma escavação arqueológica da área.

Busca pelas fundações da contramuralha, nos locais onde a estrutura é aparentemente inexistente ou está desmoronada.

Busca por elementos da 'casa do órgão'. Acima da abóbada do trânsito poderiam restar elementos que permitissem reconstituir-se a presença daquele equipamento que garantia a mobilidade do trecho final da ponte de acesso ao Forte. A documentação iconográfica do séc. $\mathrm{XX}$, mostra que àquela época restavam claras evidências daquela construção, bem como das bases do trecho fixo da ponte.

Outras questões pontuais poderiam vir a ser pesquisadas. Como, por exemplo, eventuais evidências de cozinha, de áreas de preparação de alimentos.

\section{Obras externas de defesa}

Dentre as obras externas de defesa, é mencionado com mais frequência, o fosso. Pelo que se pode observar in loco e a partir dos perfis topográficos traçados, a forma, bem como a profundidade do fosso ao longo de seu contorno, não se apresentam homogêneas. Não teria sido concluído ou foi assoreado, é uma questão inicial a ser respondida através de uma prospecção arqueológica.

Por outro lado, outras obras externas de defesa, ainda presentes, carecem de atenção. O conjunto representado pelo caminho coberto, sua banqueta e a esplanada, quase passam desapercebidos pelos visitantes. Certamente as deformações que têm sofrido ao longo do tempo, não permitem sua visualização por pessoas não afeitas às obras de terra em fortificações. Seu delineamento, ainda visível na documentação iconográfica dos primeiros anos do séc. XX, pode ser reconstituído através da pesquisa arqueológica.

\section{Área além das defesas externas da fortificação:}

\section{Escavação do forno e no entorno daquela estrutura.}

A escavação arqueológica abrangeria o interior do forno e seu entorno próximo, quando seriam buscados: 


\section{No interior do forno}

- Grelha da base do forno;

- Vestígios do material calcinado (visando a identificação da função do forno).

\section{Na área externa (entorno)}

- Vestígios de depósitos de matérias-primas (argila, areia, pedras calcárias etc.);

- Evidências do local de preparação do material a ser queimado (área de moldagem e secamento das peças - no caso de tijolos e telhas);

- Entrada da lenha (combustível);

- Agenciamento da área (acessos);

- Área de refugo;

- Área do borralho;

- Área de processamento (no caso da cal, peneiramento e para 'apagar' a cal).

\section{Escavação da Casa de Pólvora e no entorno da estrutura.}

A escavação arqueológica abrangeria o interior da Casa de Pólvora e seu entorno próximo, quando seriam buscados:

No interior:

- Estruturas divisórias internas;

- Estruturas de controle da umidade;

- Vestígios do material de suporte para os recipientes.

Na área externa (entorno):

1. Agenciamento da área (acessos);

2. Estruturas de drenagem.

\section{Prospecção na área do 'Labirinto'.}

A prospeç̧ão arqueológica estaria voltada inicialmente para a identificação da forma e distribuição das estruturas conhecidas como 'labirinto', ou seja, seu mapeamento.

Considerando as condições locais (cobertura vegetal e extensão) para o mapeamento, o que nos parece mais adequado no momento, seria a captura de imagens aéreas com o Lidar, com feixes de laser adequados à penetração na massa verde da área. O mapeamento das estruturas permitiria, além de contribuir com sua identificação, delimitar melhor a área a ser pesquisada. 
A partir do mapeamento daquelas estruturas seria possível planejar uma escavação que permitisse entender sua função e associações, e consequente relacionamento ou não com o Forte.

\section{Revisão nos estudos históricos, com ênfase no modo de vida dos construtores do Forte}

Já não são poucos os bons resultados dos estudos realizados sobre o RFPB. São conhecidos hoje grande número de documentos que tratam desde a política que levou à ocupação da área, às tratativas e providências para a construção de um posto de defesa naquela posição do rio Guaporé. As escolhas frustradas pelo regime fluvial e o acerto na definição do local definitivo que reunia condições topográficas e estratégicas. Fechando o acesso tanto pelo Guaporé quanto pelo Mamoré, naquele trecho o curso do rio se estreitava, exigindo que a navegação se fizesse através de um canal, a uma distância defensável de sua margem direita, ou seja, do Forte.

Do mesmo modo os estudos abordaram aspectos arquitetônicos e mesmo quanto aos materiais utilizados, suas fontes e tratamento. Todavia o aspecto humano, embora referido em muitas obras, que tratam de suas origens de suas etnias, não chegam ao detalhe do modo de vida daquela população transplantada para a fronteira. Questões relativas a como viviam, como e onde se alojavam, quais os alimentos e como e onde eram preparados, seus utensílios, forma de pagamento e moeda utilizada. Os serviços paralelos do cotidiano, questões de saúde que os afligia, acidentes, como eram tratados e por quem? Quanto à segurança, de que armas dispunham? E quanto à morte? Onde eram enterrados e quais os rituais associados? Estas são questões que permitiriam melhor conhecer-se o modo de vida dos homens e mulheres que construíram o Real Forte Príncipe da Beira; questões que poderiam ter grande contribuição de uma pesquisa arqueológica.

\section{Revisão na área de tombamento, incluindo estruturas externas:}

Inicialmente gostaríamos de enfocar a questão da amplitude da área de tombamento atribuída ao Real Forte Príncipe da Beira.

Levando em conta a inscrição do Bem no Livro Histórico, devemos considerar que o entorno próximo ao Forte ainda guarda muitos aspectos da história da integração daquele território às fronteiras brasileiras. Assim a área de interesse do Bem vai além das obras de defesa propriamente ditas, além de suas obras externas, inclui os portos e os antigos equipamentos 
externos que participaram de sua construção ou do próprio sistema defensivo. São testemunhos dos modos de fazer, das soluções encontradas para fazer face às condições naturais, como é o caso do regime fluvial de seus rios, com seus períodos de cheias, regulares e irregulares, dificuldades logísticas, de acesso às fontes de matéria-prima, às dificuldades no transporte.

Alguns destes testemunhos são hoje conhecidos, ainda que escondidos em meio à mata. Estruturas relacionadas à aquisição, manufatura e transporte das diferentes matérias-primas utilizadas. Outros poderão vir a ser descobertos à medida que se invista em trabalhos de reconhecimento naquele entorno.

Além do fortim da Conceição e posteriormente o Forte Bragança, são também conhecidas as ruínas de um forno e de uma casa de pólvora, mais próximas ao Forte. Uma terceira estrutura, está ainda pouco conhecida, e sobretudo não efetivamente identificada, é referida como o 'labirinto', cujas hipóteses de identificação, seja como ponto de depósito intermediário de matéria-prima para a construção do Forte, seja como ruínas da Missão de Santa Rosa Velha, estaria relacionada à história da ocupação local, às estratégias de constituição da fronteira. Todo o conjunto histórico, no nosso entender, deveria ser considerado ao abrigo da proteção legal.

\section{Sugestão de medidas de restauração e preservação das estruturas do Forte}

Ao longo dos anos que sucederam a 'descoberta' do RFPB, muito se tem tratado de sua preservação. Certamente, desde os idos de início do séc. XX, já se instalara um processo de degradação de arruinamento das antigas estruturas em pedra. 0 abandono, a perda das cobertas, a instalação de uma vegetação invasora que retomava o espaço da mata, as gameleiras se infiltrando entre as pedras das paredes, a retirada dos 'gatos' que mantinham 'amarradas' paredes justapostas, tudo convergia para o arruinamento das estruturas. Os longos e intensos períodos de chuva também forçavam a erosão dos aterros. Diferentes projetos foram elaborados, seguidas tentativas de se buscar proteger o Forte, mantê-lo livre da vegetação que insiste em povoar suas muralhas. Os trabalhos de manutenção têm surtido efeito no sentido de evitar novos danos, todavia não são suficientes para estancar o processo de deterioração. 
A proposta elaborada pelo arquiteto português Vianna de Lima, da Fundação Calouste Gulbenkian, que estudou o Forte na década de 1980, é uma das que assumiu a necessidade de que o Forte deveria ser restaurado, pelo menos em grande parte.

Mais recentemente, o Iphan levou a termo pelo menos duas experiências para preservação do Forte. A primeira, de caráter emergencial, no sentido de conter o processo de deterioração, de desmoronamento integral das paredes, com a colocação de escoras de madeira, enquanto se buscava uma solução mais definitiva. A segunda aplicada experimentalmente na área do conjunto que envolve o acesso à poterna e às latrinas. Ali, após a realização da pesquisa arqueológica, as estruturas foram remontadas e consolidadas, recuperando praticamente suas condições de uso. Uma experiência exitosa.

No nosso entender, a efetiva preservação do RFPB passa por sua restauração nos moldes adotados naquela última experiência de remontar as estruturas em risco. Uma restauração na íntegra, envolvendo as cobertas e todos os detalhes efetivamente conhecidos, seja através da pesquisa documental (inclusive fotográfica), seja da pesquisa arqueológica. Um programa de restauração, baseado na análise de risco dos dados existentes, que orientaria na sequência de estruturas que deveriam ser prioritariamente tratadas. Um programa plurianual que se voltaria, por exemplo, inicialmente para as estruturas dos quartéis internos, em seguida para as contramuralhas, e assim por diante. Cumpriria ainda ao Programa estabelecer o uso a ser atribuído àquele Bem; se como pousada, em uma parceria público-privada, seria esta uma questão ainda em aberto.

Mesmo ao longo do processo de restauração, seria muito importante dar-se uso às estruturas concluídas, de modo a garantir sua preservação.

Estudos posteriores, mormente arqueológicos, permitiriam integrar outros equipamentos no Programa de Restauração, como é o caso tanto da 'casa de pólvora', quanto do 'forno', ou outros tantos que viessem a ser descobertos.

Quanto às ruínas do Conceição/Bragança, esta área sempre à mercê do regime fluvial, sujeita às grandes cheias, requer uma atenção diferenciada. Possivelmente o mais indicado, além de um estudo direcionado a resgatar antigos remanescentes de suas estruturas e uso, seria buscar-se consolidar suas ruínas, mesmo considerando se tratar de uma atividade provavelmente recorrente. 
Todas estas ações perderiam muito do seu sentido se não estiverem integradas a um Programa de divulgação e visitação que estimulasse o usufruto do legado de gerações passadas.

\section{Produtos decorrentes das tomadas aéreas.}

Os produtos decorrentes das tomadas aéreas, tais como fotografias, modelos digitais, curvas de nível, e ortofotocarta, estão disponíveis, mediante solicitação através do endereço marcos@brasilarqueologico.com.br

Cumpre salientar que a iniciativa da Diretoria do Patrimônio Histórico e Cultural do Exército DPHCEx de promover uma Visita de Orientação Técnica ao Real Forte Príncipe da Beira, em Costa Marques - RO, possibilitou a troca de experiências entre profissionais de diferentes áreas, num esforço para enfocar sob diferentes óticas as tratativas para a preservação daquele Bem. Os primeiros frutos já se fazem sentir através do envolvimento conjunto de arqueólogos do Laboratório de Arqueologia da UFPE e engenheiros do Instituto Militar de Engenharia - IME, que já buscam realizar uma série de estudos que servirão de apoio às discussões que certamente terão lugar para a tomada de decisões quanto ao futuro do RFPB.

Esta visita de orientação técnica (VOT) contou com apoio integral da 17ạ Brigada de Infantaria de Selva e de seu 1o PEF (Pelotão Especial de Fronteira) a quem agradecemos toda a assistência recebida.

Vale ressaltar ainda que a 17ạ Brigada de Infantaria de Selva através de seu 10 PEF (Pelotão Especial de Fronteira) tem mantido o Forte, livre da vegetação invasora e garantido que eventuais visitantes possam ter acesso sem riscos tanto para as pessoas quanto para as estruturas.

É doloroso ver um forte, tão enfraquecido que precisa se apoiar em escoras para não ruir. $E$ este é um processo em andamento, que não será interrompido pelas escoras, apenas um pouco retardado. Será necessária uma atuação enérgica e continuada que permita de fato restaurar, não apenas as estruturas, mas a própria dignidade do Real Forte Príncipe da Beira, a nível, não apenas do esforço de seus idealizadores e construtores, mas ainda de sua significância para a formação do território brasileiro. 


\section{Referências}

Albuquerque, M. A. G. M. Remanescentes Materiais do Período Pombalino No Amapá Revista Brasileira de Arqueometria, Restauração e Conservação, Olinda, v.1, n. 1, p. 16, 2006, 2006.

ALBUQUERQUE, M. A. G. M. Arqueologia da Fortaleza de São José de Macapá. 2008, Revista DaCultura N14.

AlBuquerque, M. A. G. M.; AlBuquerque, V. C. L. Fortificação e Humanidade. In: Jeanine Mafra Migliorini. (Org.). Sítios Históricos e Centros Urbanos. 1aed.Ponta Grossa (PR): Atena Editora, 2018, v., p. 135-147.

AlBuQuerque, M. A. G. M.. Arqueologia de Unidades de Defesa. In: Fernanda Codevilla Soares. (Org.). Arqueologia das fortificações: perspectivas. 1ed.Florianópolis: Lagoa, 2015, v., p. 9-37.

ALBUQUERQUE, M. A. G. M.; LUCENA, V. Arqueologia Amazônica - O potencial arqueológico dos assentamentos e fortificações de diferentes bandeiras. In: Encontro Internacional de Arqueologia Amazônica, 2008, Belém-PA. Anais do Museu Paraense Emilio Goeldi.

BARBOSA, F. D. A.; BARBOSA, R. D. S. Política portuguesa de ocupação territorial do Brasil: o Forte Príncipe da Beira. [S.I.]: [s.n.], Rio de Janeiro, 1986. Disponível em: <bit.ly/2oY3nKQ>. Acesso em: outubro 2020

BARCELOS, G. S. Forte Príncipe da Beira: conhecimento, valoração e preservação. - Instituto do Patrimônio Histórico e Artístico Nacional, Dissertação (Mestrado em Preservação do Patrimônio Cultural), Rio de Janeiro, 2018.

BARROSO, L. D. S. Real Forte Príncipe da Beira: ocupação oeste da Capitania de Mato Grosso e seu processo construtivo (1775-1783). Porto Alegre: Versos Seremos, 2015.

BARROSO, L. S. Real Forte Príncipe da Beira, Sentinela Avançada. Brasilia: Priint Impressões Inteligentes, 2019.

CASTRO, A. H. F. Muralhas de Pedra, Canhões de Bronze e Homens de Ferro: fortificações do Brasil de 1504 a 2006. Rio de Janeiro: Fundação Cultural do Exército Brasileiro, 2009.

CASTRO, A. H. F. A engenharia do medo. Nossa História - Ano3 / N. 27, janeiro 2006.

DICIONÁRIO CARTOGRÁFICO. 4a Ed., Cêurio de Oliveira, Rio de Janeiro, 1993.

FERRAZ, A. L. P. Real Forte Príncipe da Beira. Revista do Patrimônio Histórico e Artístico Nacional no02. [S.I.]: [s.n.], 1938.

FERREIRA, M. R. Nas Selvas Amazônicas. São Paulo: Biblos, 1961.

MARQUES, F. L. T. Acompanhamento Arqueológico das Escavações de Prospecção das Fundações das Estruturas do Forte Príncipe da Beira, Belém, 2008. 
NORAT, R. C.; COSTA, M. L. Characterization, usage and provenance of building rocks in the Fortress of São José of Macapá (Amazon, Brazil). ENGINEERING GEOLOGY, v. 253, p. 214-228, 2019.

REIS E SILVA, H. A Terceira Margem - Parte LXXVI Real Forte do Príncipe da Beira - XIII Relatos Pretéritos do Forte Príncipe da Beira Antônio Leôncio Pereira Ferraz (1978) p.2. Bagé, 2020 https:f/www.ecoamazonia.org.br/2020/10fterceira-margem-parte-lxxiif p.4

TEIXEIRA, P. R. R. Forte Príncipe da Beira. Revista DaCultura, Ano III, no04. Rio de Janeiro, Ano III, no4: [s.n.], 2003. Disponível em: <bit.ly/2MiJp6E>. Acesso em: outubro 2020. 